\title{
Hydro-chemo-mechanical modelling of tunnels in sulfated rocks
}

\author{
A. RAMON*, E. E. ALONSO* and S. OLIVELLA*
}

\begin{abstract}
A modelling procedure to address the tunnel-anhydritic rock interaction is described in this paper. The model incorporates the basic physico-chemical phenomena involved in rock swelling, often observed during excavation and subsequent operation of tunnels. It includes $(a)$ a provision for rock damage during tunnel excavation, $(b)$ the precipitation of gypsum crystals in discontinuities and $(c)$ a stressdependent relationship between swelling strains and mass of gypsum precipitation. The model includes hydro-mechanical coupling and the transport of sulfate salts dissolved in the massif water. Rock damage is described by the development of a network of fractures that increases permeability and allows gypsum crystal growth. Field information, laboratory data and monitoring records available for Lilla tunnel, located in the province of Tarragona, Spain and excavated in Tertiary anhydritic claystone, were selected as a convenient benchmark case to test model capabilities. Predictions and measurements (swelling records of the unlined tunnel floor and swelling pressures against a structural invert) were found to agree reasonably well.
\end{abstract}

KEYWORDS: finite-element modelling; monitoring; soft rocks; tunnels \& tunnelling

\section{INTRODUCTION AND BACKGROUND}

Geological formations rich in anhydrite, when crossed by tunnels, may experience severe heave displacements, which usually manifest at floor level. Later, when lining is in place, recorded swelling pressures on load cells are often high or very high (one to several $\mathrm{MPa}$ ). Case histories have been reported for many decades (Grob, 1972, 1976; Henke, 1976; Einstein, 1979, 1996; Wittke \& Pierau, 1979; Kovári et al., 1988; Wittke, 1990, 2006; Steiner, 1993; Madsen et al., 1995; Amstad \& Kovári, 2001; Kovári \& Descoeudres, 2001; Wittke-Gattermann \& Wittke, 2004; Anagnostou, 2007; Alonso et al., 2013).

Anhydrite formations belonging to the Triassic Keuper period are frequent in central Europe. The rock massif excavated in Lilla tunnel located in the province of Tarragona, Spain, which will be analysed in this paper, is a recent Tertiary deposit that exhibits a number of features (a clay matrix, variable proportions of anhydrite and gypsum and a history of tectonic deformations) found in Keuper rocks.

Early attempts to introduce ground swelling into tunnel design relied on the determination of a 'swelling law'. A classic example is the Huder-Amberg procedure to determine, under oedometric conditions, a relationship between confining stress and swelling deformation (Huder \& Amberg, 1970; Grob, 1972; Einstein et al., 1972; Kovári et al., 1988). Madsen (1999) and ISRM (1989) describe similar procedures to determine the swelling law. Kovári et al. (1988) derived a simple and clever procedure to find a tunnel characteristic curve in the case of swelling ground, which incorporates a swelling law. This contribution opens up the possibility of designing tunnel linings by requiring compatibility between lining deformations and the 'swelling characteristic curve'.

Manuscript received 27 February 2017; revised manuscript accepted 10 July 2017. Published online ahead of print 22 August 2017.

Discussion on this paper closes on 1 April 2018, for further details see p. ii.

* Division of Geotechnical Engineering and Geosciences, Department of Civil and Environmental Engineering, Universitat Politecnica de Catalunya, Barcelona, Spain.
Historically, the next step was to introduce the swelling law as an imposed 'external deformation' into numerical analyses, typically using finite elements; contributions in this regard are provided by Wittke \& Rißler (1976), Gysel (1977, 1987), Fröhlich (1986) and Anagnostou (1992, 1995). Some researches describe coupled flow-deformation procedures (Anagnostou, 1993; Wittke-Gattermann, 1998; Heidkamp \& Katz, 2002, 2004; Wittke, 2003; Wahlen \& Wittke, 2009; Schädlich et al., 2013). Swelling laws may include time, refer to anisotropic conditions and reproduce stress paths expected by tunnel excavations (Barla, 2008). Kramer \& Moore (2005) describe swelling rock behaviour by means of viscoelastic models.

The calculation procedures developed for swelling nonsulfated clay rocks experience significant difficulties in anhydrite-related swelling. In sulfated rocks, swelling strains are mainly a consequence of gypsum crystal precipitation in aqueous solutions (Ramon \& Alonso, 2013; Alonso et al., 2013). This chemical reaction is described by kinetic equations, which require information on the exposed anhydrite and gypsum surfaces to water, the mass rates of anhydrite dissolution and gypsum precipitation, the current sulfate and ionic concentration of the massif water and the saturation concentration of gypsum and anhydrite. The exposed surfaces of sulfate minerals in a real environment depend on the structural arrangement of the rock constituents and also on fissuring, which is, in part, a response to tunnelling-induced stress changes. These interactions are representative at the scale of field problems and can hardly be reproduced by a 'point' estimation, which is the concept behind the formulation of constitutive models. From a laboratory perspective, the 'point' is reproduced by a small sample and its representativeness is therefore very limited.

Mass rates of dissolution/precipitation require information that is sometimes derived from tests involving the direct interaction of crystals and water - a circumstance far from the physics of clayey sulfated rocks. Saturation concentrations depend on the pressure acting on crystals, temperature and on the remaining salts dissolved in pore water.

Reproducing all these cross-effects in small 'representative' samples therefore appears to be a daunting task. The 'swelling laws' proposed for expansive clay rocks are not 
adequate to describe sulfate-induced swelling and realistic alternatives are required.

In Lilla tunnel, sulfated clayey rock (Alonso et al., 2007) swelling was attributed to the precipitation of gypsum crystals from supersaturated sulfate solutions in the massif water. The first hypothesis explored to explain the supersaturation was the evaporation of water at the rock-tunnel atmosphere interface. Evaporation led to a straightforward kinetic law for the rate of gypsum precipitation, given by

$$
\frac{\mathrm{d} m_{\text {gyp }}}{\mathrm{d} t}=\frac{\mathrm{d} V_{\mathrm{w}}^{\text {evap }}}{\mathrm{d} t} \rho_{\mathrm{w}} c
$$

where $m_{\mathrm{gyp}}$ is the precipitated mass of gypsum, $t$ is time, $V_{\mathrm{w}}^{\text {evap }}$ is the volume of evaporated water at the interface, $\rho_{\mathrm{w}}$ is the water density and $c$ is the current sulfate concentration of water. Alonso \& Olivella (2008) explored this mechanism, which simply states that the precipitated gypsum mass is given by the sulfate concentration in the water.

Figure 1 shows the calculated strains in a vertical section under the tunnel axis. The plot was consistent with continuous extensometer records but the numerical prediction was strongly dependent on two assumptions, which were later found unlikely to be true: $(a)$ a deep water table below the tunnel floor and $(b)$ a very high ratio between volumetric deformations and the mass of precipitated gypsum. The first assumption led to the prediction of an evaporation front at some depth below the tunnel floor where gypsum precipitation (and therefore swelling strains) was maximum. The second assumption indicated that the mass of precipitated gypsum was orders of magnitude lower than the equivalent heave of the tunnel floor.

The case of Pont de Candí (Alonso \& Ramon, 2013; Ramon \& Alonso, 2013) provided field confirmation that supersaturated sulfate solutions eventually leading to gypsum precipitation did not require any evaporation process. Earlier works had already indicated that water solutions in the presence of anhydrite reach supersaturated conditions with respect to gypsum. This observation led to a modified computational model for the swelling phenomenon, which was described by Ramon et al. (2009). Later, it was developed in mathematical terms, for one-dimensional conditions, by Oldecop \& Alonso (2012). Ramon \& Alonso (2013) describe a generalised formulation, which is included in the coupled flow-deformation finite-element code Code_Bright (DGEGS, 2017).

Figure 2 illustrates the key concept. Water in a dense argillaceous rock percolates predominantly along fissures, be they natural or induced. Anhydrite crystals exposed on the fissures dissolve and create a supersaturated solution capable of precipitating as gypsum, especially if gypsum crystals are found in the vicinity. Fig. 3 shows the growth of needle-like gypsum crystals in an open discontinuity (gypsum crystallises in the monoclinic system).

The swelling-induced damage observed at Pont de Candí and in Staufen and Lochviller (Goldscheider \& Bechtel, 2009; Sass \& Burbaum, 2010; Alonso \& Ramon, 2013; Ruch \& Wirsing, 2013) was triggered by a change in hydrologic conditions. Tunnelling is different because it results in major changes in stress around the excavation. Stress controls the equilibrium concentrations of anhydrite and gypsum and it probably has a direct effect on crystal growth. In addition, stress changes and the excavation procedure (notably blasting) result in a damaged zone around the tunnel. In brittle rocks, damage implies the opening of new or existing fissures. Two associated effects are the enhancement of crystal growth and a change in flow regimes around the tunnel and, possibly, large-scale hydrogeological changes (Butscher et al., 2011).

This paper describes the modelling assumptions and numerical analysis of Lilla tunnel during excavation and the installation of a support and a concrete invert. Records of floor swelling and pressures against the invert will be compared with calculations. The model is an evolution of previous developments with the purpose of addressing a number of phenomena, as outlined above.

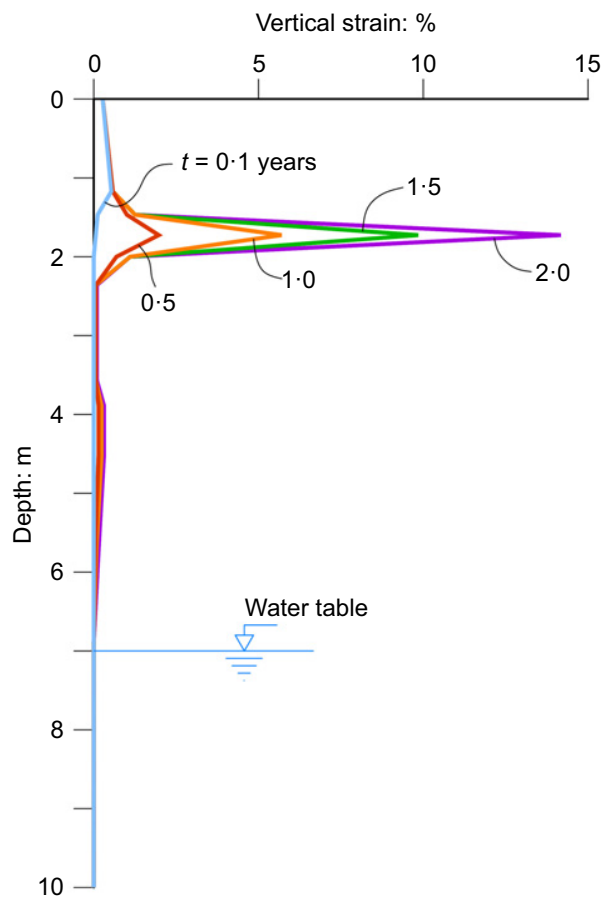

(a)

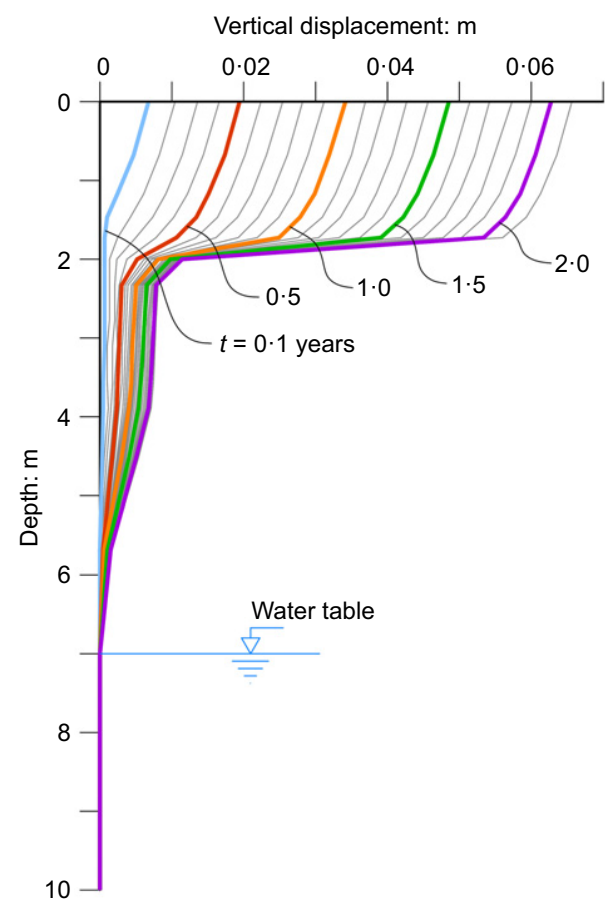

(b)

Fig. 1. Calculated evolutions of (a) vertical strains and (b) accumulated vertical displacements due to crystallisation of gypsum due to water evaporation above a phreatic surface (Alonso \& Olivella, 2008) 


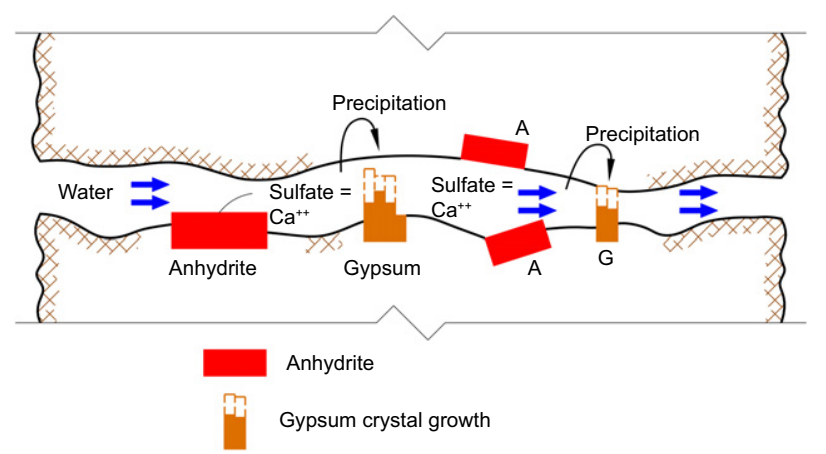

Fig. 2. Conceptual representation of the process of expansions due to anhydrite dissolution and gypsum precipitation

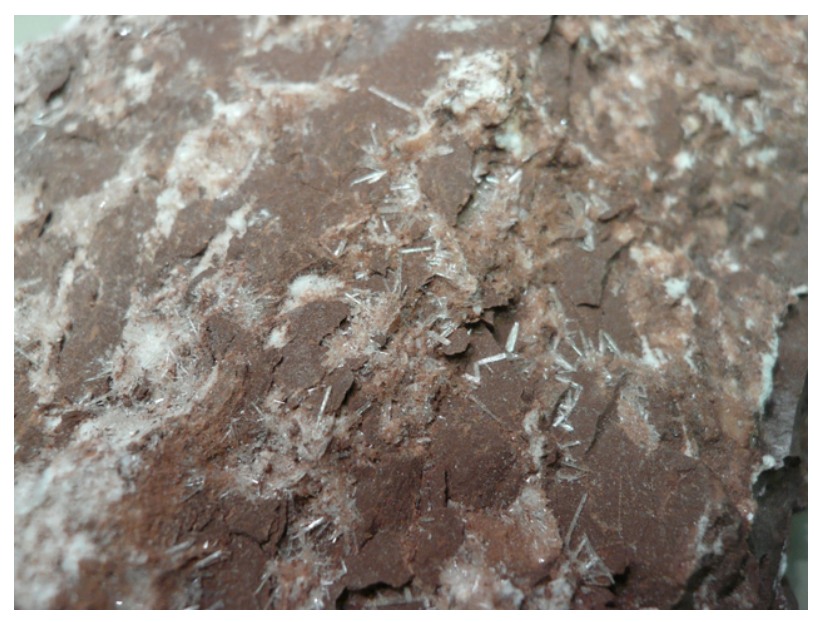

Fig. 3. Growth of gypsum crystals on the surface of a rock discontinuity (rock sample recovered from Lilla tunnel floor during the field investigation period)

\section{MODEL DESCRIPTION}

The rock is represented as a continuous porous medium in saturated or unsaturated states. Two scales are distinguished. The large scale requires the formulation of classic balance equations for the mass of solid particles, the pore liquid and pore gas. Liquid flow carries solutes and their balance is also formulated. Static equilibrium conditions complete the formulation. The local scale includes the rock mechanical behaviour and a set of additional phenomena introduced to reproduce anhydrite and gypsum dissolution/precipitation and its effect on the rock.

Ramon \& Alonso (2013) formulated the set of balance and equilibrium equations, which are summarised in the Appendix. This section presents the modelling of local phenomena.

\section{Rock damage}

Rock damage is associated with the development of fissures. Two mechanisms are considered: stress-induced opening and crystal growth. The general concept to include fracturing was presented by Olivella \& Alonso (2008) in connection with gas flow. The idea here is to 'embed' a virtual planar opening in an otherwise continuum element when the calculated maximum principal strain in extension reaches a predetermined critical value. If this critical strain is zero, the fracture already exists. The change in crack aperture is equal to the product of the tensile strain in excess of the threshold

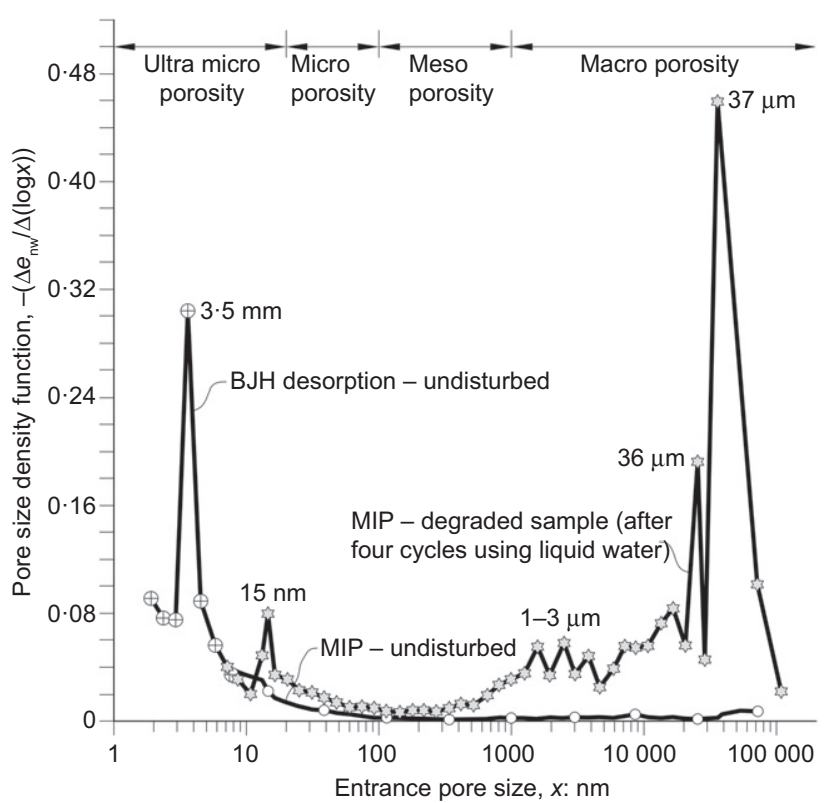

Fig. 4. Pore size distribution of Lilla claystone (modified from Pineda et al. (2014)); BJH, Barrett-Joyner-Halenda; MIP, mercury intrusion porosimetry

value and a characteristic material length. The orientation of a new fracture may be taken to be perpendicular to the principal tensile strain orientation. In the simplest application of the method, favoured here, the effect of a fracture opening in a given finite element is 'smeared' in the element and the permeability is modified following a cubic law.

Opening of discontinuities is explained by $(a)$ effective stress changes due to tunnel excavation and subsequent changes in pore pressure and boundary conditions and (b) precipitation of gypsum crystals.

Precipitation of gypsum crystals requires supersaturated conditions in the massif water. Therefore, no crystal precipitation is expected under unsaturated conditions. It is also assumed that crystals cannot develop in the small pores of a dense clay rock. The porosity of undisturbed Lilla clay ranges from $0 \cdot 06$ to $0 \cdot 10$. Fig. 4 (Pineda et al., 2014) shows the pore size distribution of undisturbed Lilla claystone, revealing a unique range of very small pores in the range $2-10 \mathrm{~nm}$.

It is further assumed that crystal precipitation is only possible in open cracks with a minimum opening. Discussing the growth of crystals in pores, Scherer (1999) stress that cracks and pits are the sites favouring the nucleation of crystals. In a review of gypsum crystallisation and its effect on the deterioration of natural stones, Charola et al. (2007) refer to observations of gypsum crystal growth in natural pores. They also stress the tendency of gypsum to accumulate and to generate internal stresses in the rock, which enhances deterioration. Charola et al. reported the size of crystals as observed through microscopy, mentioning values in the range of microns.

Crack opening for the initiation of crystal precipitation was approximated in the way described in the next section. Fig. 4 shows also the pore size distribution of degraded Lilla claystone after cycles of drying and wetting. The large 'macropores' developed correspond to internal cracks. The size (opening) of these cracks $(0 \cdot 02-0 \cdot 1 \mathrm{~mm})$ is many orders of magnitude larger than the undisturbed pore size.

The mass of precipitated gypsum is determined by means of a kinetic law adopted for the numerical analysis of Pont de Candí (Ramon \& Alonso, 2013). In fact, the Pont de Candí 
active zone and the excavated rock in Lilla belong to the same stratigraphic unit. The distance between the central pillars of Pont de Candí and the portal of Lilla tunnel is $600 \mathrm{~m}$.

The kinetic law is given by

$$
\frac{\mathrm{d} m_{\mathrm{gyp}}}{\mathrm{d} t}=\sigma_{\mathrm{c}} \kappa \xi_{\mathrm{gyp}} \phi_{\mathrm{gyp}}\left(\mid\left(\frac{\omega_{1}^{\mathrm{m}}}{\omega_{1_{\mathrm{sat}, \text { gyp }}^{\mathrm{m}}(T, p)}(T)}-1 \mid\right)^{\theta}\right.
$$

in which $\omega_{1}^{\mathrm{m}}$ is the mass fraction of dissolved sulfate in water, $\phi_{\text {gyp }}$ is the current volumetric fraction of gypsum $\left(\mathrm{m}^{3} / \mathrm{m}^{3}\right)$, $\omega_{1_{\text {sat, gyp }}}^{\mathrm{m}}$ is the equilibrium mass fraction in presence of gypsum, $\sigma_{\mathrm{c}}$ is the specific surface of gypsum $\left(\mathrm{m}^{2}\right.$ of crystal surface $/ \mathrm{m}^{3}$ of medium), $\kappa$ is a constant describing the rate of dissolution/precipitation of mass of gypsum $\left(\mathrm{kg} / \mathrm{s} \cdot \mathrm{m}^{2}\right), T$ is absolute temperature and $p$ is the pressure applied on the crystals; the coefficients $\theta=1$ and $\eta=2$ were maintained. The product $\sigma_{\mathrm{c}} \kappa$ acts as a single parameter, called the compound kinetic coefficient in Ramon \& Alonso (2013). It is difficult to calculate it from its two basic components because of the complexities of natural rock masses.

In addition, the assumption implicit in equation (2) is that the specific surface of gypsum crystals is fully in contact with water. However, the conceptual model proposed here (Fig. 2) suggests that only crystals existing in discontinuities contribute to chemical reactions. The parameter $\xi_{\mathrm{gyp}}=+1$ if precipitation occurs and $\xi_{\mathrm{gyp}}=-1$ in the case of dissolution. A similar equation is adopted for anhydrite.

The measured temperature in Lilla tunnel (close to $15^{\circ} \mathrm{C}$ ) indicates that, in all the circumstances analysed here, gypsum precipitates and anhydrite dissolves. This is a consequence of the equilibrium mass fractions of gypsum and anhydrite $\left(\omega_{1_{\text {sat gyp }}}^{\mathrm{m}}\right.$ and $\left.\omega_{1_{\text {sat, anh }}}^{\mathrm{m}}\right)$ at the temperature prevailing in the rock under the tunnel floor (Fig. 5).

Dissolved salts and minerals other than calcium sulfate modify the saturation concentrations of gypsum and anhydrite. Recent contributions on this topic (Serafeimidis \& Anagnostou, 2013, 2015; Anagnostou et al., 2015) report the effect of the solute mineralogical content on gypsum or anhydrite equilibrium concentrations.

The effect of salt content in water on gypsum and anhydrite equilibrium concentrations was addressed by performing chemical interaction calculations with the help of the program PHREEQC (Parkhurst, 1995; Parkhurst \& Appelo, 1999). Fig. 5 shows some results. Increasing the salt concentration (sodium chloride $(\mathrm{NaCl})$ ) from pure water to $220 \mathrm{mg} / \mathrm{l}$ and $440 \mathrm{mg} / \mathrm{l}$ of dissolved salts increased the equilibrium concentration of gypsum. Interestingly, the

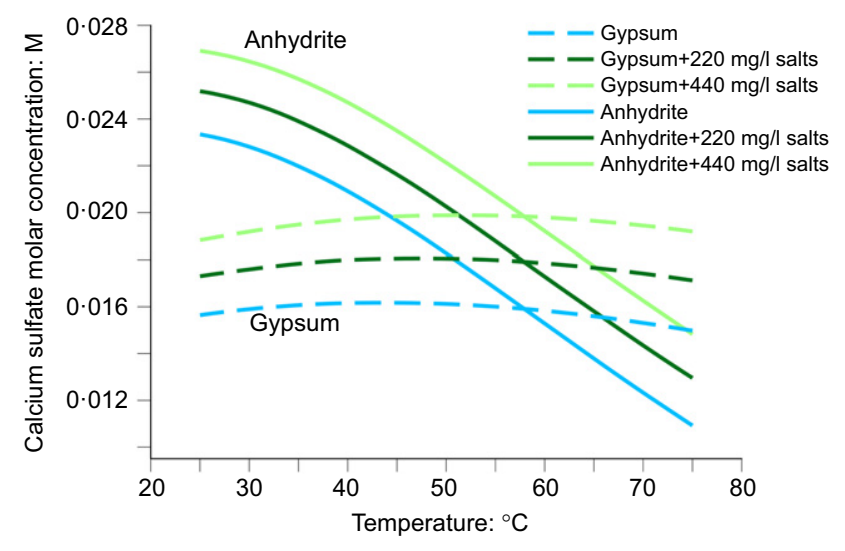

Fig. 5. Solubility of gypsum and anhydrite for different temperatures in water with different chemical compositions; the salt considered is sodium chloride anhydrite concentration increased in similar proportions. The implication is that the potential for gypsum precipitation in the presence of anhydrite does not change much when other salts are included in the analysis. Fig. 5 also indicates a significant effect of temperature. However, the critical temperature beyond which the anhydrite equilibrium concentration became lower than the gypsum value (around $60^{\circ} \mathrm{C}$ ) was not much affected. In the analysis of Lilla tunnel described later, the tunnel rock temperature was fixed at $15^{\circ} \mathrm{C}$. This temperature was adopted in view of temperature readings $\left(12 \cdot 4-16 \cdot 8^{\circ} \mathrm{C}\right)$ on seeping massif water collected in the vault of the tunnel.

\section{Precipitated gypsum mass and rock straining}

Geometrical considerations justify that crystal growth in pores and fissures may lead to a volume change in excess of the precipitated gypsum volume. Fig. 2 also serves to illustrate this idea.

Oldecop \& Alonso (2012) and Ramon \& Alonso (2013) proposed a swelling correction to transform the mass of precipitated crystals into rock deformation

$$
\frac{\mathrm{d} \varepsilon_{i}}{\mathrm{~d} t}=\frac{\gamma_{i}}{\rho_{\text {gyp }}} \frac{\mathrm{d} m_{\text {gyp }}}{\mathrm{d} t}
$$

where $\gamma_{i}$ is a coefficient measuring the 'bulking' effect of precipitation in the rock mass in the $i$ direction, $\rho_{\mathrm{gyp}}$ is the gypsum density $\left(\mathrm{kg} / \mathrm{m}^{3}\right)$ and $\varepsilon_{i}$ is the rock deformation in the $i$ direction induced by gypsum precipitation. There is not much information about the magnitude of $\gamma$ and the expected effect of confining stress in reducing its value. It may be accepted as a modelling parameter to be determined by matching experiments or field observations.

Further information was obtained by interpreting swelling experiments on artificial mixtures of kaolin (selected because of its low expansivity) and fine powder of anhydrite (grains in the range $5-16 \mu \mathrm{m})$ reported by Huber et al. (2015). Samples were first compacted to a low porosity $(n=0 \cdot 29-0 \cdot 35)$ and were subsequently wetted under varying vertical stress in an oedometric cell. Swelling was recorded in time and, after equilibrium, the remaining masses of gypsum and anhydrite were determined. Kaolin swelling was also measured and subtracted from the total strain to determine the expansion attributed to gypsum precipitation.

The laboratory data reported by Huber et al. (2015) were interpreted with the purpose of obtaining information on the coefficient $\gamma$. Calculated values of $\gamma$ for the vertical direction, $\gamma_{\mathrm{vG}}$, are plotted in Fig. 6 in terms of the confining stress. The plotted curves correspond to alternative procedures to

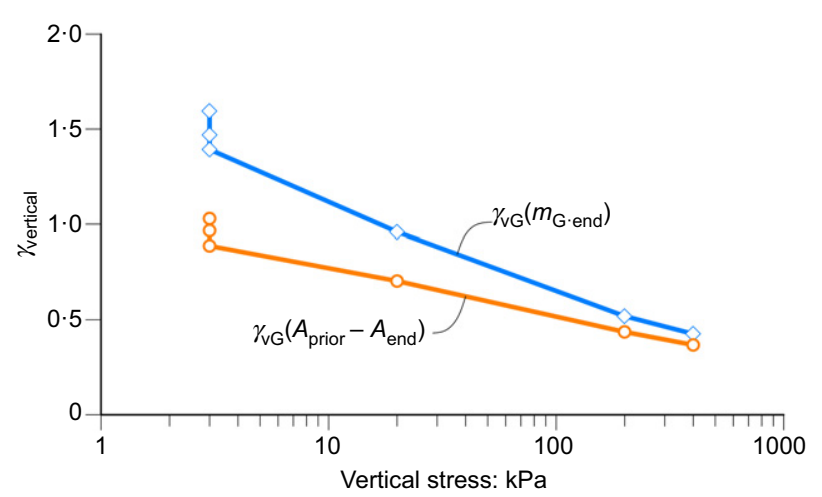

Fig. 6. Bulking parameter calculated from test results reported by Huber et al. (2015) 
calculate the precipitated gypsum mass. The values of $\gamma_{\mathrm{vG}}\left(m_{\mathrm{G} \text {.end }}\right)$ and $\gamma_{\mathrm{vG}}\left(A_{\text {prior }}-A_{\text {end }}\right)$ in Fig. 6 were calculated by means of equation (3). The values of $\gamma_{\mathrm{vG}}\left(m_{\mathrm{G} \text {.end }}\right)$ were taken from data of the mass of gypsum at the end of the tests, reported by Huber et al. (2015). The values of $\gamma_{\mathrm{vG}}\left(A_{\text {prior }}-A_{\text {end }}\right)$ were approximated from the reported data on the masses of anhydrite present in the samples before and after the tests. These data were used to estimate the mass of precipitated gypsum during the tests, assuming that the decrease in mass of anhydrite present in the samples after the tests resulted from the dissolution of anhydrite and its subsequent precipitation into gypsum. The mass of precipitated gypsum was calculated by means of the stoichiometric mass balances of the chemical reactions of dissolution of anhydrite and precipitation of gypsum and the difference between the mass of anhydrite in the samples before and after the tests.

The two procedures yielded similar results: $\gamma$ reached maximum values of $1-1.6$ for low confinement $(3 \mathrm{kPa})$ and experienced a progressive reduction to $\gamma=0.3$ as the confining stress increased to $400 \mathrm{kPa}$.

Admittedly, Lilla claystone is not a granular porous medium but its dense network of fissures, especially for advanced states of degradation, may be regarded as a feature favouring the identification of the fissured rock as a porous medium at a convenient scale. The analysed experiments indicate that high $\gamma$ values (in excess of two) are unlikely. They also suggest that the effect of stress may be approximated by exponentially decaying functions such as

$$
\begin{aligned}
& \gamma_{i}=\gamma_{\max } \mathrm{e}^{-b \sigma_{i}^{\prime}} \text { for } \sigma_{i}^{\prime}>0 \\
& \gamma_{i}=\gamma_{\max } \text { for } \sigma_{i}^{\prime}=0
\end{aligned}
$$

where $b$ is a model parameter. Equation (4) was proposed by Ramon \& Alonso (2013) without experimental support. The effective stress in equation (4) is suggested as the controlling stress field. Total and effective stresses in the active zone below Lilla tunnel are probably very similar because of the low values of pore pressures below the tunnel floor.

The set of governing equations summarised in the Appendix and the additional information discussed here were solved by means of the finite-element code Code_Bright (Olivella et al., 1994, 1996; DGEGS, 2017).

\section{NUMERICAL ANALYSIS}

Lilla tunnel, located in the province of Tarragona, Spain, carries the high-speed railway line connecting Madrid and Barcelona. It was excavated in 2001-2002 by a conventional drill and blast technique in two stages (head and bench), and is $2034 \mathrm{~m}$ long. It has a horseshoe-shaped cross-section, a net cross-sectional area of $117 \mathrm{~m}^{2}$ and a cover varying between 32 and $110 \mathrm{~m}$. It crosses an Eocene sulfated claystone strongly folded and sheared by the Alpine Orogeny, which raised the coastal Catalonian mountain chain, located a short distance away.

The excavated claystone was a soft to medium rock of low porosity $(2 \cdot 6-5 \%$ when undisturbed; higher values (up to $10 \%$ ) were also measured in some locations closer to the tunnel excavation) whose mineralogical content was dominated $(50-70 \%)$ by illite and paligorskite clay minerals. Anhydrite was present in significant but variable proportions $(7-50 \%)$. The gypsum content was low $(0-7 \%)$. The remaining minerals were dolomite and quartz.

The excavated tunnel was initially supported by sprayed concrete and a $300 \mathrm{~mm}$ thick cast-in-place concrete, which included a flat floor slab. Severe heave of the slab was recorded immediately after completing the works in the period from October 2002 to December 2003. Vertical sliding micrometers were thus installed and rock cores were recovered from borings drilled from the tunnel floor slab. Cores were tested to gather data on rock density, solid-phase components and water content in some cross-sections, in particular cross-section $411+600$ located at a distance $400 \mathrm{~m}$ from the north portal. This cross-section is analysed in detail in this paper.

In addition, a $250 \mathrm{~m}$ long curved invert was built in the tunnel stretch showing maximum heave rates with the purpose of gaining experience on the performance of a closed lined section. Load cells located at the rock-invert contact provided swelling pressure records over 2 years (2003-2004). The heave recorded in the flat slab, extensometer records, vertical profiles of gypsum and anhydrite content, swelling pressures against the invert and its vertical heave were compared with numerical predictions, as detailed later in the paper.

Major repair works to Lilla tunnel were carried out immediately after the period discussed so far. The original horseshoe-shaped section was transformed into a circular section supported by heavily reinforced high-strength concrete and the tunnel entered service in December 2006. Alonso et al. (2013) describe the case in detail.

This paper examines the initial behaviour of the tunnel, essentially in the period 2002-2003. The response of Lilla tunnel is characterised by strong variability when different cross-sections and measurements in a given cross-section (heave displacements, swelling pressures) are examined. This heterogeneous response may be attributed not only to the irregular distribution of anhydrite concentration but also to details of natural rock fracturing, which are very strongly affected by intense tectonic activity. Fracturing enhances rock permeability and the potential for gypsum crystal growth. This situation should be considered when comparing field data with the response of the developed homogeneous numerical analysis.

Chainage $411+600$ is the reference position for the cross-section analysed. At this location, the tunnel cover is $77 \mathrm{~m}$. Besides the vertical profiles of rock properties (Fig. 7) and swelling deformations, time records of heave displacements of the flat slab and swelling pressures against the invert arch built later on were available in the vicinity of this section.

Figure 8 shows the geometry and boundary conditions used for computations under plane-strain conditions. The tunnel crown was $25 \mathrm{~m}$ below the upper boundary and the rock thickness below the original tunnel flat floor was $33 \mathrm{~m}$. A vertical stress equivalent to $52 \mathrm{~m}$ of rock was applied on the upper boundary of the analysis domain to reproduce the expected vertical stress state around the tunnel. Horizontal in-situ stresses were not measured. A value $K_{0}=2$ was adopted in view of the intense tectonism in the area. The excavation was simulated in a single step.

The process of fracture opening and precipitation/ dissolution of sulfated minerals was activated in the entire discretised rock mass. The model parameters and complementary observations are listed in Table 1.

An elastic behaviour was adopted for the rock matrix. This hypothesis probably had a minor effect on the swelling phenomena, dominated by gypsum precipitation. On the other hand, fracture opening introduced in the model was controlled by the prevailing vertical stresses below the floor slab, which are mainly controlled by vertical equilibrium (except in the proximity of the abutments), which will not depend much on the mechanical rock model.

A non-saturated state was imposed in the model rock mass during the excavation process to avoid numerical difficulties during the excavation process. Once stresses equilibrated, after excavation, the water level was raised gradually to a level 


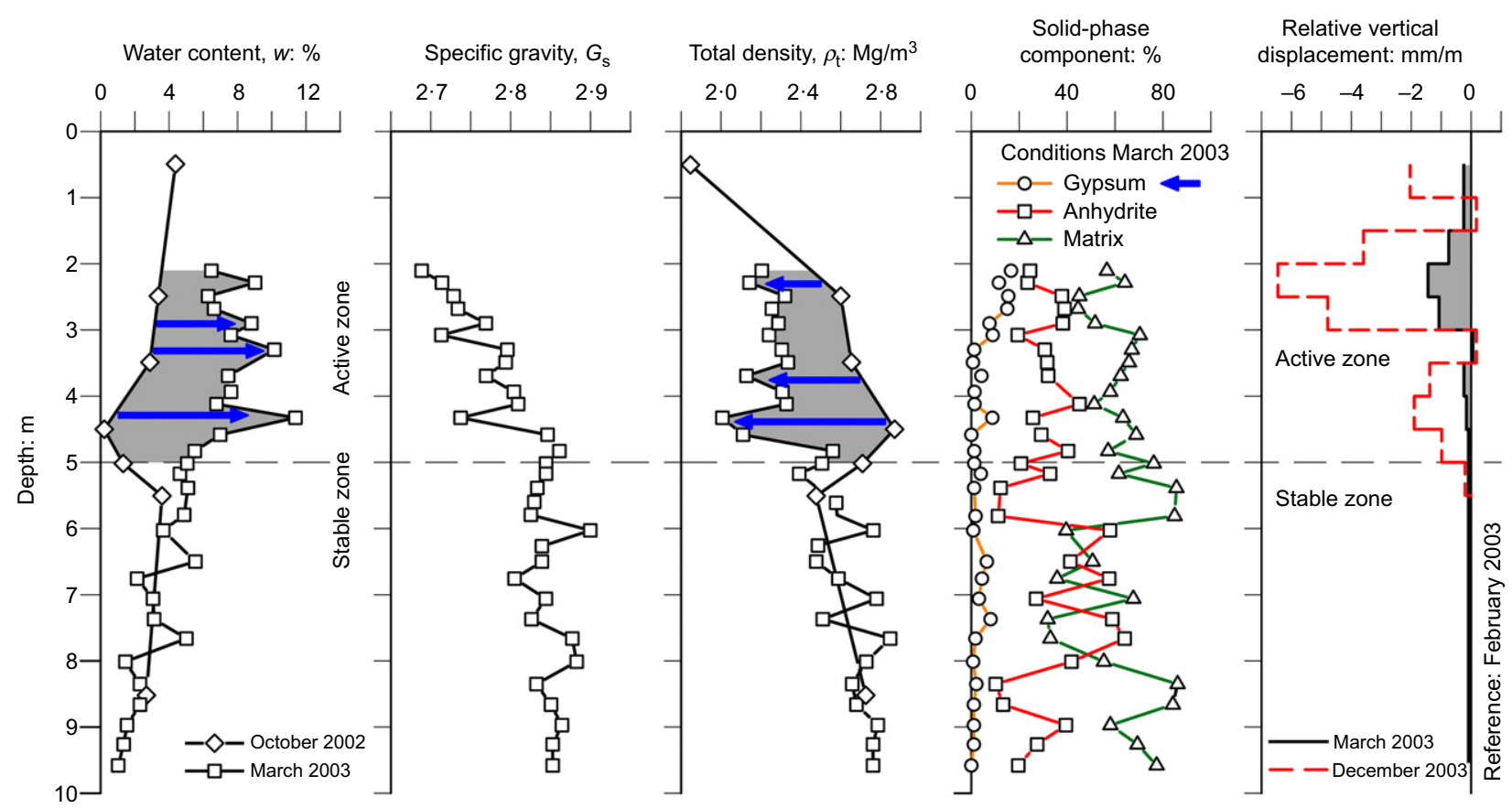

Fig. 7. Geotechnical and mineralogical characterisation of the rock at chainage $411+600$ (invert arch) and vertical displacements measured by the continuous extensometer installed in the axis (Alonso et al., 2013)

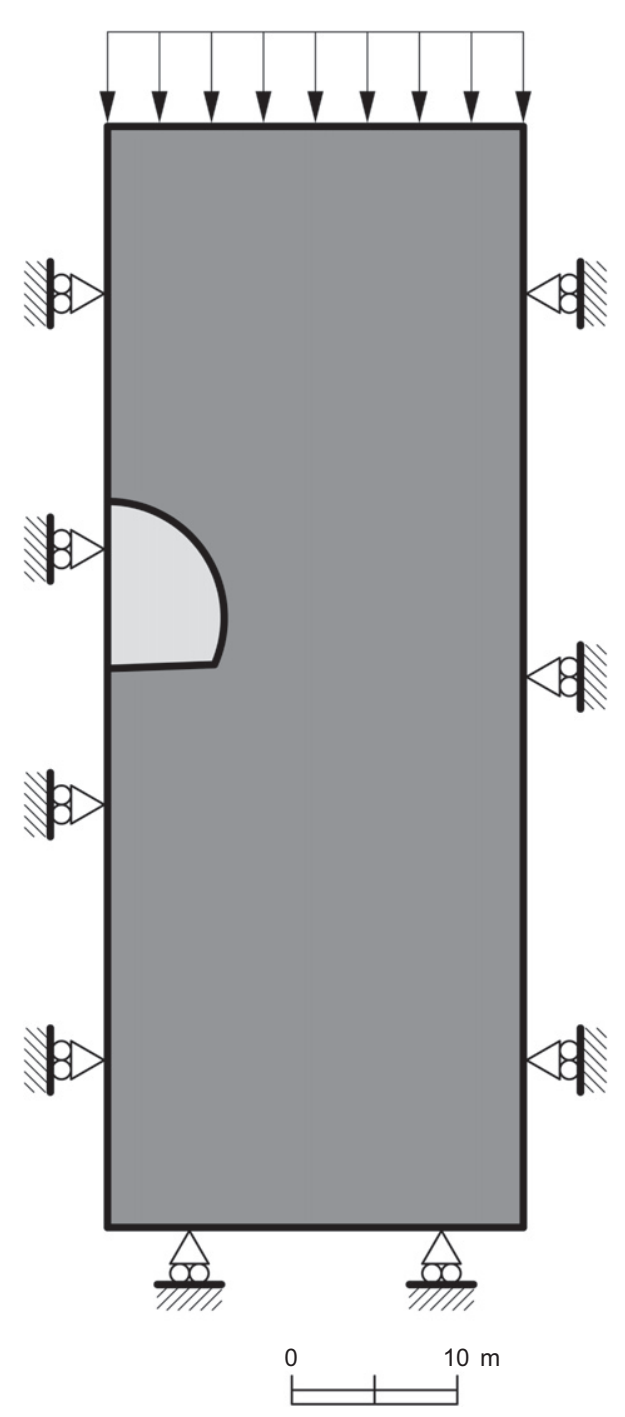

Fig. 8. Geometry and boundary conditions of the analysis domain
$1 \mathrm{~m}$ above the position of the tunnel floor. At the same time, zero water pressure was fixed at the tunnel floor itself. The relative humidity imposed on the tunnel abutments and vault was $99.9 \%$ (equivalent to a small suction $\psi=0.13 \mathrm{MPa}$ ); this condition implies very small water evaporation towards the tunnel.

Rock permeability was uncertain. The claystone matrix was expected to have low permeability. However, boreholes drilled for core recovery and the installation of continuous extensometers became filled with water within a few weeks, revealing the effect of fractures. An intrinsic permeability of $K=2 \times 10^{-14} \mathrm{~m}^{2}$ was estimated for the rock mass.

The fracture model described earlier in the paper requires specification of the initial fracture aperture $\left(a_{0}\right)$, the threshold tensile strain $\left(\varepsilon_{0}\right)$ and the spacing between fractures, $s$. Visual examination of cores indicated that fractures could be identified but they were essentially closed. It was thus decided to adopt $a_{0}=0$ and $\varepsilon_{0}=0$. The dense fracturing translated into a short spacing between planes, $s=50 \mathrm{~mm}$. A maximum fracture opening of $a_{\max }=2 \mathrm{~mm}$ was adopted to avoid unrealistically high values of permeability.

Gypsum mass ratios in cores recovered below the active zone were small (5-10\%). Anhydrite mass ratios at the same locations were much higher $(40-50 \%)$. Their variations with depth were quite irregular (Fig. 7). The initial values for the mass ratios of gypsum and anhydrite adopted in the numerical analysis were $10 \%$ and $40 \%$, respectively. The initial gypsum mass fraction (Ramon \& Alonso, 2013) has a small effect on calculated gypsum precipitation.

As already mentioned, gypsum crystals do not grow in very small volumes such as claystone pores. The ultimate reason for this is associated with the molecular dynamics that explain the precipitation of gypsum molecules. If a discontinuity is closed, crystals will have also difficulty growing. So, the relevant issue is to determine a threshold fracture opening that allows gypsum crystal growth. A practical way to do this is to attribute the lower limit of the active zone to a given threshold fracture opening. Then, if the maximum tensile strain induced by tunnel excavation is calculated at the lower boundary of the active zone, the critical fracture aperture for 
Table 1. Parameters for analysis of Lilla tunnel

\begin{tabular}{|c|c|c|}
\hline & Value & Observations \\
\hline \multirow{2}{*}{$\begin{array}{l}\text { Rock matrix } \\
\text { Elastic modulus, } E\end{array}$} & & \\
\hline & $1000 \mathrm{MPa}$ & $\begin{array}{l}\text { Measured } E \text { values in unconfined compression tests on densest cores } \\
\text { ranged from } 2000 \text { to } 4000 \mathrm{MPa} \text {. A lower } E \text { value was adopted to } \\
\text { account for disturbance around the tunnel }\end{array}$ \\
\hline Poisson's ratio, $v$ & $0 \cdot 2$ & \\
\hline At-rest pressure coefficient, $K_{0}$ & 2 & Intense rock folding suggests a high $K_{0}$ value \\
\hline Density of inert minerals, $\rho_{\mathrm{s}}$ & $2 \cdot 85 \mathrm{Mg} / \mathrm{m}^{3}$ & Tests in cores \\
\hline Gypsum density, $\rho_{\text {gyp }}$ & $2 \cdot 3 \mathrm{Mg} / \mathrm{m}^{3}$ & \\
\hline Anhydrite density, $\rho_{\mathrm{anh}}$ & $2 \cdot 96 \mathrm{Mg} / \mathrm{m}^{3}$ & \\
\hline \multicolumn{3}{|l|}{$\begin{array}{l}\text { Rate equations for dissolution and } \\
\text { precipitation }\end{array}$} \\
\hline $\begin{array}{l}\text { Mass fraction of gypsum in water } \\
\text { for saturated conditions, no stress applied, } \\
\omega_{0 \text { lsat,gyp }}^{\mathrm{m}}\end{array}$ & $2 \cdot 028 \times 10^{-3}$ & \\
\hline \multicolumn{3}{|l|}{$\begin{array}{l}\text { Mass fraction of anhydrite in water } \\
\text { for saturated conditions, no stress applied, } \\
\omega_{0}^{\mathrm{m}} \text { lsat, anh }\end{array}$} \\
\hline Initial gypsum porosity, $\phi_{\mathrm{ni}}^{\mathrm{gyp}}$ & $0 \cdot 1$ & Average value derived from measurements on cores \\
\hline Initial anhydrite porosity, $\phi_{\mathrm{ini}}^{\mathrm{anh}}$ & $0 \cdot 4$ & Average value derived from measurements on cores \\
\hline $\begin{array}{l}\text { Compound kinetic coefficient, } \\
\qquad\left(\sigma_{\mathrm{c}} \kappa\right)_{\mathrm{gyp}}=\left(\sigma_{\mathrm{c}} \kappa\right)_{\mathrm{anh}}\end{array}$ & $10 \times 10^{-4} \mathrm{~kg} / \mathrm{m}^{3}$ & Adjusted to reproduce heave observations \\
\hline Coefficients of kinetic law (equation (2)) & $\theta=1, \eta=2$ & $\begin{array}{l}\text { A quadratic description of dissolution/precipitation rates describes } \\
\text { the processes better }\end{array}$ \\
\hline $\begin{array}{l}\text { Minimum fracture aperture for precipitation, } \\
a_{\text {crit }}\end{array}$ & $88 \cdot 5 \mu \mathrm{m}$ & Corresponds to the maximum depth of active layer (see text) \\
\hline \multicolumn{3}{|l|}{$\begin{array}{l}\text { Volumetric strains induced by gypsum crystal } \\
\text { growth }\end{array}$} \\
\hline $\begin{array}{l}\gamma_{\max } \\
b\end{array}$ & $\begin{array}{l}2 \\
2\end{array}$ & See text \\
\hline \multicolumn{3}{|l|}{ Fracture development } \\
\hline $\begin{array}{l}\text { Threshold tensile principal strain to initiate } \\
\text { fracture opening, } \varepsilon_{0}\end{array}$ & 0 & Fractures assumed to exist before tunnel excavation \\
\hline Initial aperture of fractures, $a_{0}$ & 0 & Fractures assumed to be closed initially \\
\hline Maximum aperture of fractures, $a_{\max }$ & $2 \mathrm{~mm}$ & Selected to avoid extremely high permeability of swelled rock \\
\hline Spacing of fractures, $s$ & $50 \mathrm{~mm}$ & $\begin{array}{l}\text { Approximated from observations in cores. Lilla claystone is densely } \\
\text { fissured }\end{array}$ \\
\hline \multicolumn{3}{|l|}{ Flow transport } \\
\hline Initial open porosity, $\phi_{\text {ini }}$ & 0.06 & \\
\hline $\begin{array}{l}\text { Intrinsic initial permeability of porous } \\
\text { rock, } K\end{array}$ & $2 \times 10^{-14} \mathrm{~m}^{2}$ & Estimated value for the initial state of the fractured rock; see text \\
\hline
\end{tabular}

crystal growth is calculated by applying this (uniform) strain to a length equal to the fracture spacing. This calculation provided a value of $a_{\text {crit }}=88.5 \mu \mathrm{m}$.

The numerical analysis developed for swelling at Pont de Candí (Ramon \& Alonso, 2013) provided a reference case for the selection of some rock parameters because the active zone in Pont de Candí is located in the same geological unit as Lilla. The two cases are, however, quite different because of the effect of tunnel excavation in modifying rock conditions - a fundamental aspect absent at Pont de Candí. As a first choice for the parameters to be used in the kinetic equation, a first set of calculations was run with Pont de Candí back-calculated values $\left(\sigma_{\mathrm{c}} \kappa=3.5 \times 10^{-4} \mathrm{~kg} / \mathrm{m}^{3}\right.$.s and $\gamma_{\max }=1 ; b=2$; see equations (2) and (4)). The resulting heave displacements calculated for Lilla remained below the measurements. The parameter $\sigma_{\mathrm{c}} \kappa$ incorporates the effect of the crystal specific surface and it is reasonable to accept that the excavation-induced fissuring resulted in a substantial increase in anhydrite surface exposed to dissolution by water flowing in discontinuities. Therefore, $\sigma_{\mathrm{c}} \kappa$ was increased to $10 \times 10^{-4} \mathrm{~kg} / \mathrm{m}^{3}$.s in the calculations reported below and the bulking coefficient for zero pressure stress was increased to $\gamma_{\max }=2$. These values provided a reasonable fit to the time records of floor heave displacements near chainage $411+600$.

\section{MODEL PREDICTIONS}

First stage of construction: flat tunnel floor

The measured vertical displacements of the axis of the tunnel flat slab at chainage $411+540$ for a period of 15 months are compared with calculations in Fig. 9(a). Chainage $411+540$ is the closest to chainage $411+600$ where floor heave records are available. As shown in the figure, the agreement is reasonably good for the first 4 months but the measured heave accelerated during the following 2 months to revert again to a slower rate later on. Fig. 9(b) provides a more complete picture of the performance of the simulation. Here, calculated heave is compared with six measured heave records in a $540 \mathrm{~m}$ long stretch (from chainage $411+380$ to chainage $411+920$ ). The predictions approximately follow the mean trend for the first part of the recording time but underestimate the field records in later months.

Field heterogeneity explains some of the discrepancies. The accelerations in vertical displacements observed in some records at specific times suggest that rock degradation was capable of increasing the kinetic precipitation/dissolution reactions by increasing the exposed surface of anhydrite.

The confining effect of the abutments explains the bulging shape of the calculated heave (Fig. 10). No precise levelling data across the width of tunnel floor are available 


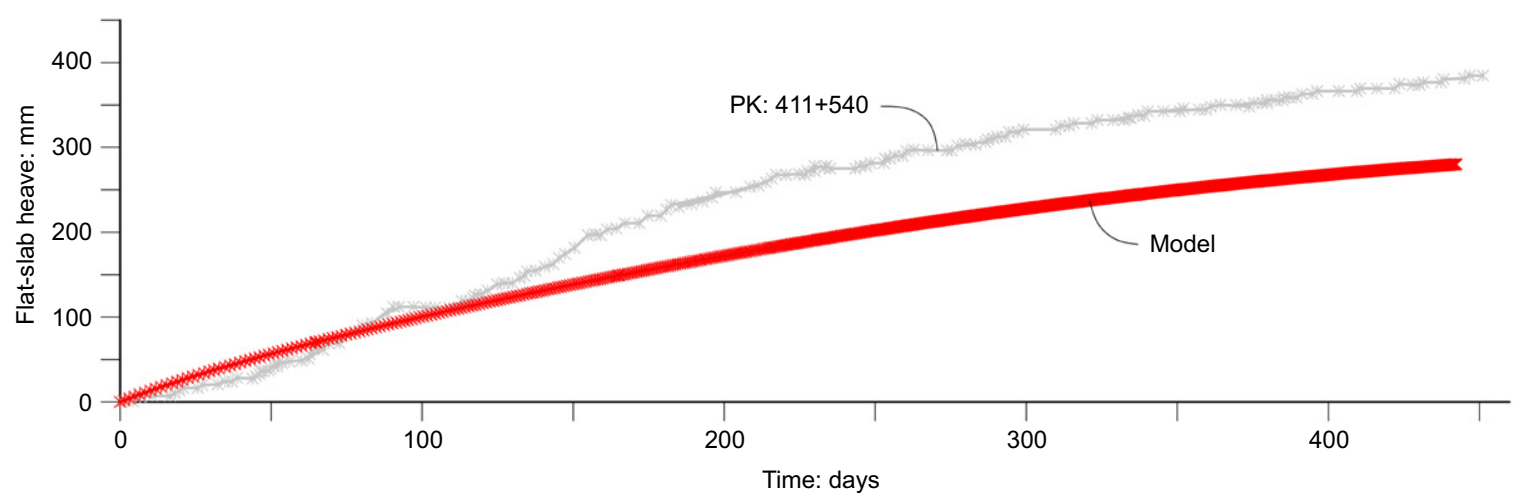

(a)

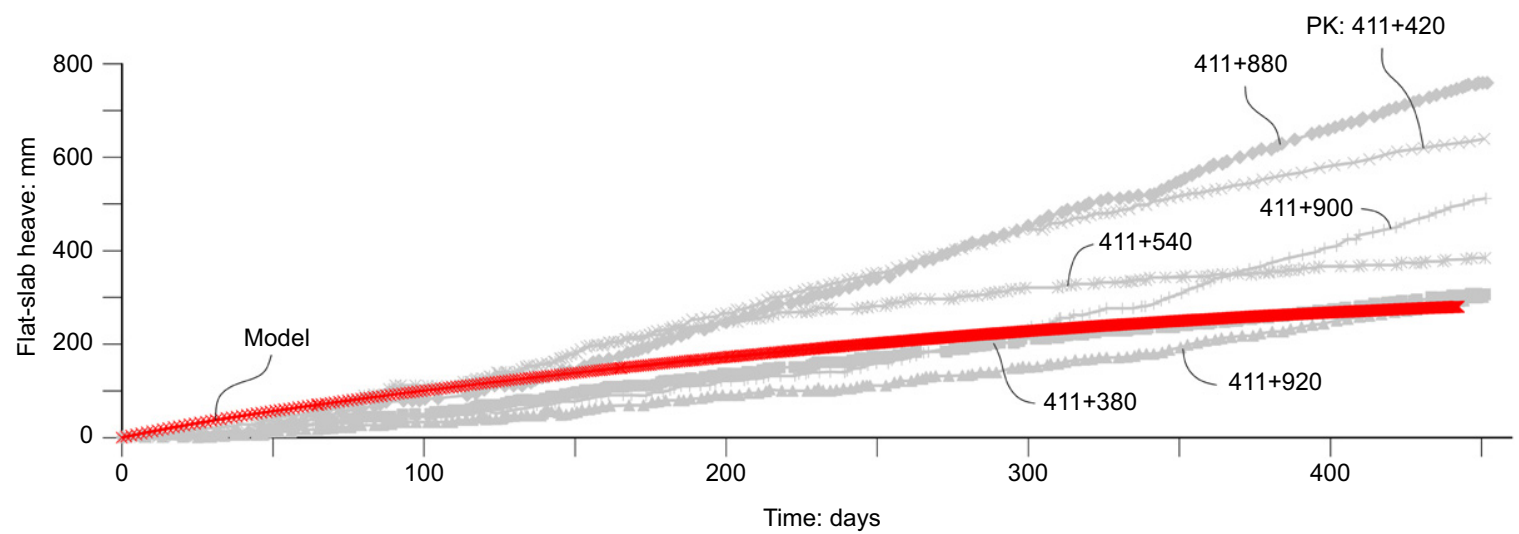

(b)

Fig. 9. Vertical displacements calculated at the centre of the tunnel floor and field measurements (2002-2003) of heave at sections with flat slab

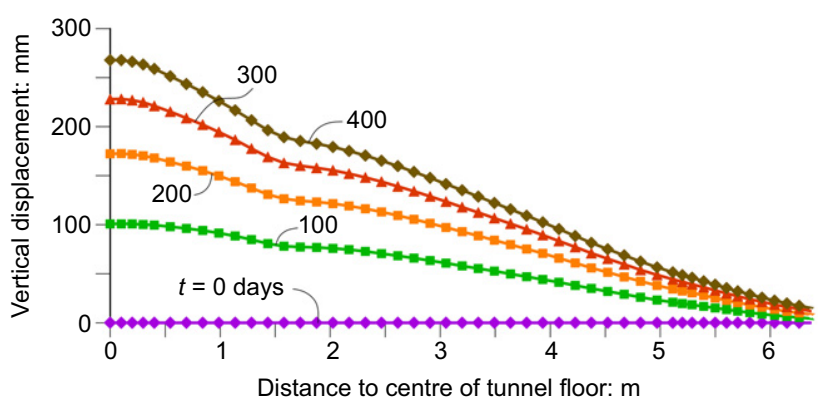

Fig. 10. Distribution of calculated vertical displacements across the tunnel floor due to precipitation of gypsum; $t=0$ days corresponds to initiation of the gypsum precipitation process

but bulging shapes were visually observed at some locations. Slab cracking was also widespread - a feature not contemplated in the simulation.

The calculated variations of vertical strains with depth and time are plotted in Fig. 11 at the tunnel axis and at a position $3.50 \mathrm{~m}$ away from it.

Figure 12 shows the calculated evolutions of gypsum and anhydrite volumetric fractions, revealing that gypsum volume increased in parallel with a reduction in anhydrite volume. Fig. 13 shows the gypsum and anhydrite volume fractions determined in cores recovered at chainage $411+600$ after the detection of expansions. The sulfate mineral contents below a depth of around $5 \mathrm{~m}$ are representative of natural conditions before tunnel excavation. The average final content of anhydrite within the active zone $(0 \cdot 25-5 \mathrm{~m})$ compares well with calculations, whereas the calculated gypsum content is somewhat larger than the laboratory determinations.
Figure 14 shows the calculated intrinsic permeability and fracture opening. Over time, permeability in the active zone increased by six orders of magnitude. No measurements for Lilla are available, but Butscher et al. (2011) report a similar increase in the permeability of the "excavation disturbed zone' in tunnels excavated in sulfated rocks. The calculated increase in joint aperture was limited to $2 \mathrm{~mm}$, a value that was reached, at the end of the simulation (1 year), in the upper $2 \mathrm{~m}$ of the swelling zone.

Two-dimensional maps of a few variables at the end of the 1 year simulation period provide additional information. Vertical strains as high as $15-20 \%$ were calculated at shallow depths below the floor near the tunnel axis (Fig. 15). The strains decreased toward the abutments because of the effect of increasing vertical stress.

Gypsum and anhydrite transformations were found to extend some distance beyond the tunnel span (Fig. 16). Their progression downwards was limited by the threshold fracture opening required for gypsum crystallisation. This is shown in Fig. 17(a), which shows the fracture opening, which was prevented below the abutments because of the confinement they provided. The fracture opening was also found to decrease with depth under the tunnel floor because of the increasing stress intensity and the imposed limitation on crystal growth. Fig. 17(b) shows the calculated permeability values. The calculated intrinsic permeability within the active zone ranged between $10^{-8}$ and $10^{-9} \mathrm{~m}^{2}$. It decreased quickly in the lower boundary towards the value adopted for undisturbed rock.

Second stage of construction: concrete invert arch

The invert arch was built in January 2004 from chainage $411+556$ to chainage $411+860(300 \mathrm{~m}$ in length) after the 'free' swelling period discussed previously. The boundary 


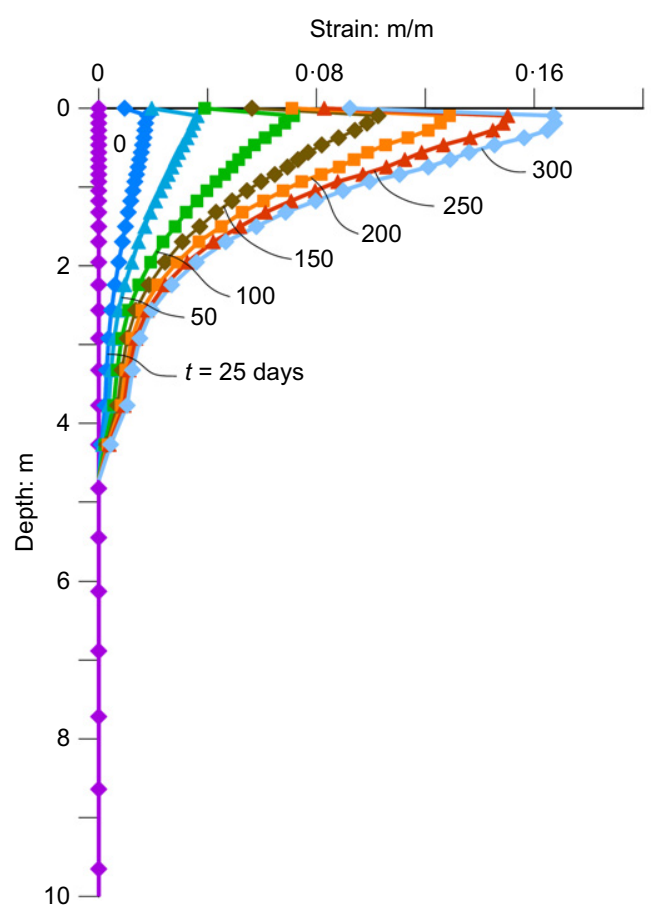

(a)

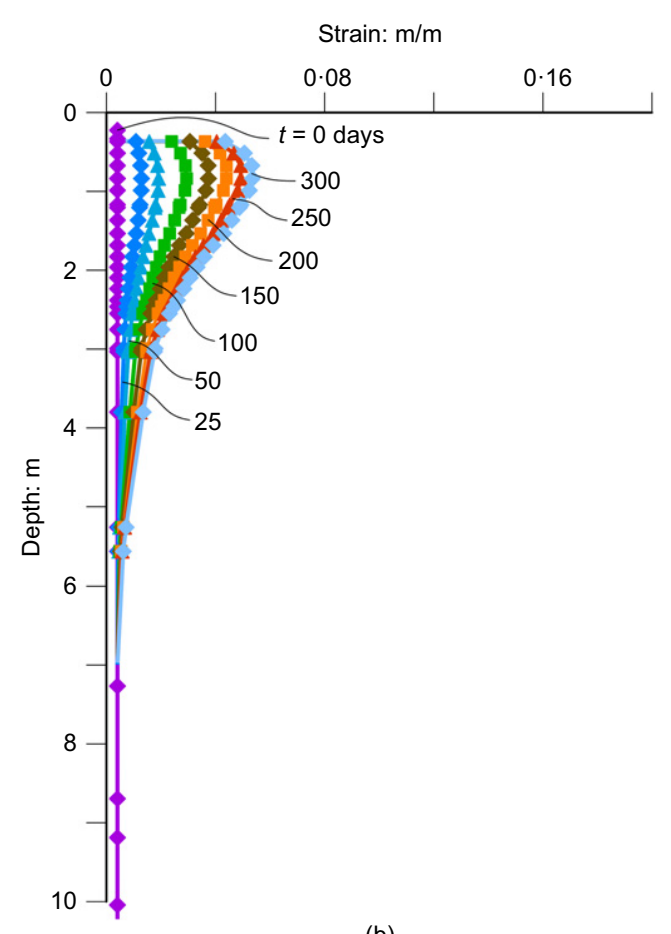

(b)

Fig. 11. Depth distribution of calculated vertical strains in the upper $10 \mathrm{~m}$ below the flat slab: (a) at the axis of the tunnel; (b) at a vertical profile located at $3.5 \mathrm{~m}$ away from the axis of the tunnel; $t=0$ days corresponds to the beginning of the crystallisation process after tunnel excavation

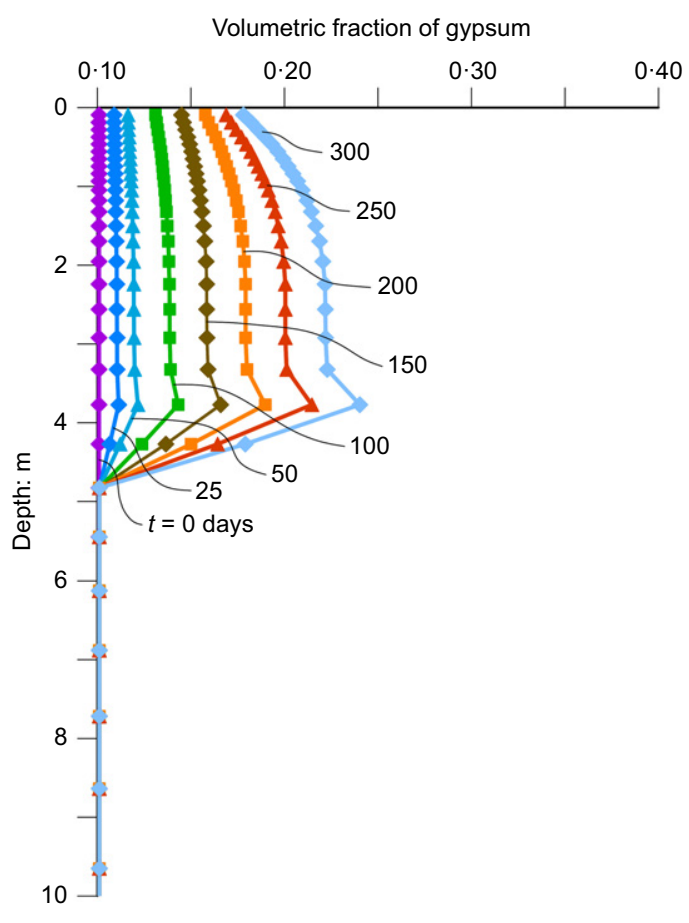

(a)

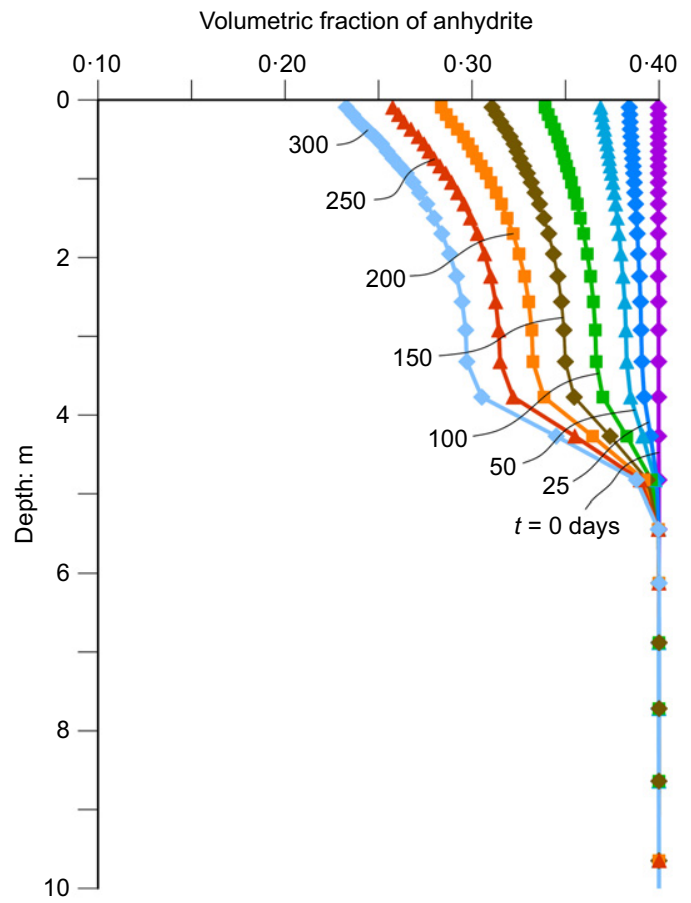

(b)

Fig. 12. Depth distribution of calculated volumetric fractions of (a) gypsum and (b) anhydrite in the upper $10 \mathrm{~m}$ below the flat slab at the axis of the tunnel; $t=0$ days corresponds to the beginning of the crystallisation process

conditions and tunnel discretisation are shown in Fig. 18. A partial excavation of the active zone was required to build the arch. The excavated rock corresponds to the most damaged upper zone. The analysis performed is approximate in the sense that the initial undisturbed state was adopted for the rock mass. The simulation involved an initial full excavation until equilibrium of water pressures was reached. No chemical reactions were allowed during this period. Then, the concrete lining, including the invert arch, was built and the process of sulfate dissolution/precipitation was activated. The analysis performed serves to analyse the effect of the structural reaction provided by the tunnel invert 
on the swelling phenomenon. Since the rock mass was characterised in an identical manner to the previous free swelling case, comparison of the two cases was facilitated.

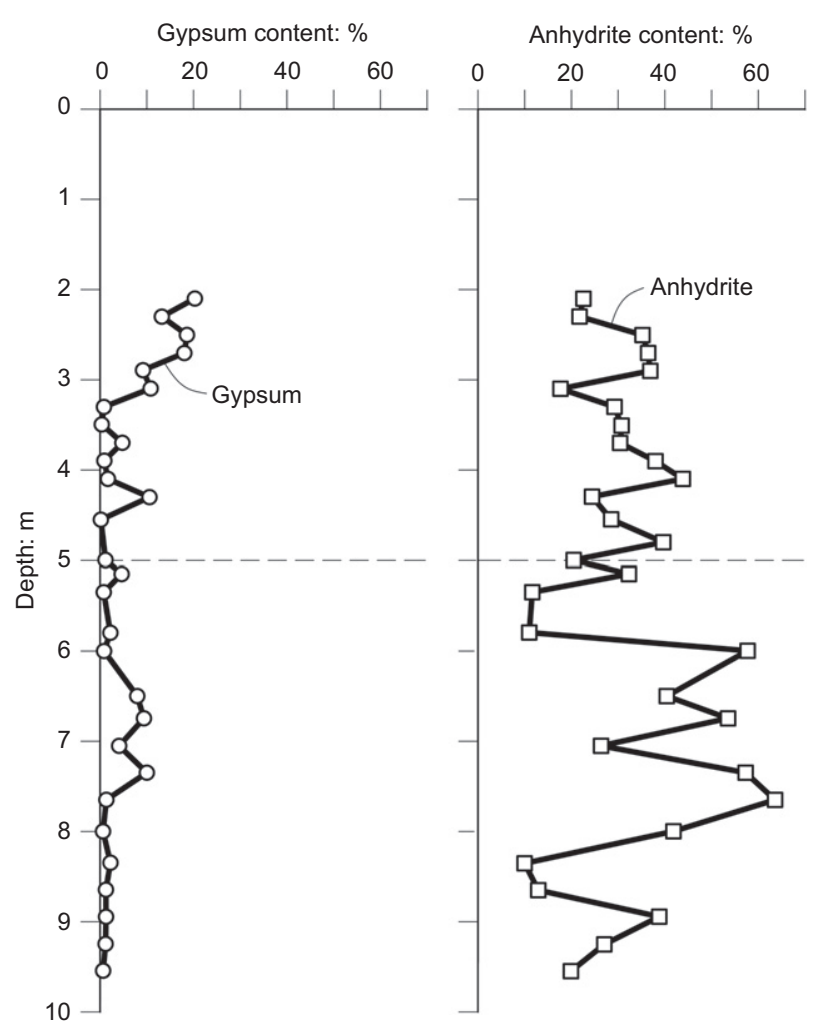

Fig. 13. Variation with depth of gypsum and anhydrite contents $(\%$ in volume) found in cores recovered from a borehole at chainage $411+600$, after detection of floor slab heave
Load cells located at the tunnel axis and in a position close to the abutments recorded the development of contact pressures over time. Fig. 19 shows pressure records for chainage $411+609$, the closest section to the reference section (chainage $411+600$ ) for parameter identification. The figure shows the development of vertical stresses calculated at the rock-invert contact in the central axis and directly below the 'footing' connecting the invert and the tunnel lining. The simulation managed to capture the development of pressures with reasonable precision. The stiff 'fixed' point under the abutment experienced the maximum swelling pressure. Similar pressure-time records along the invert showed a significant reduction in axial pressure when compared with cell records close to the tunnel abutments.

Figure 20 shows the calculated and measured vertical displacements experienced by the invert at the tunnel axis. The calculations overestimated the actual displacement records significantly. In the numerical model, the resisting structure was a $40 \mathrm{~cm}$ thick invert arch. It is unclear if the space between the invert and the original position of the tunnel floor was filled with concrete. This situation may explain the discrepancy between the numerical predictions and the heave measurements. The tunnel section was later transformed into a heavily reinforced circular structure and the invert arch was demolished. The effect of the invert arch in reducing heave, even with its moderate curvature, was quite effective.

\section{CONCLUSIONS}

Research contributions by several groups over the past decade have resulted in better understanding of the chemical and physical phenomena behind the severe expansivity observed in tunnels excavated in anhydritic formations. The finite-element model described in this paper is believed to represent the fundamental aspects of basic mechanisms.

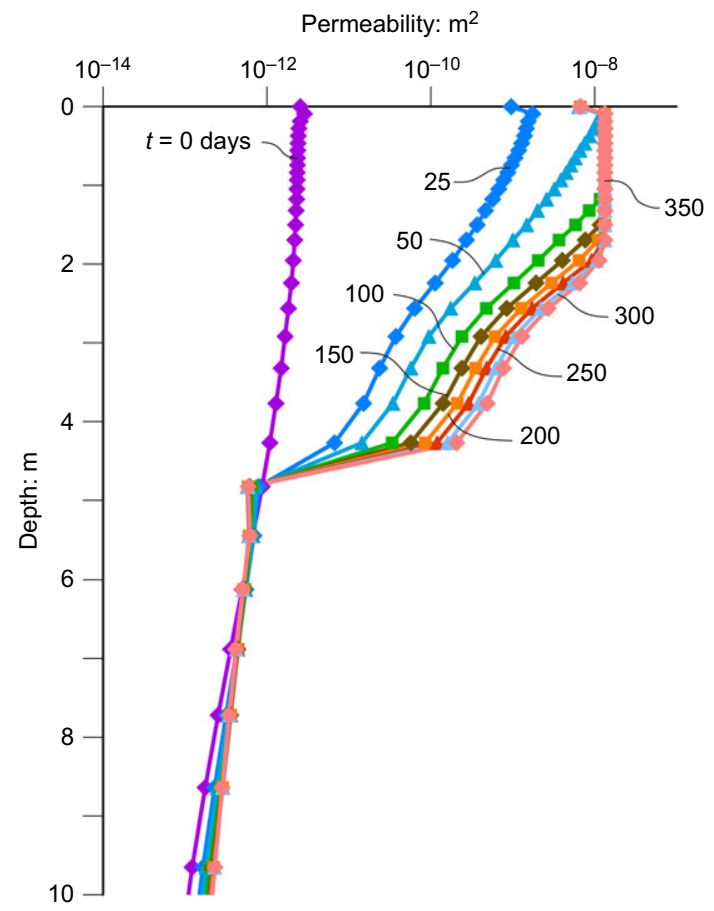

(a)

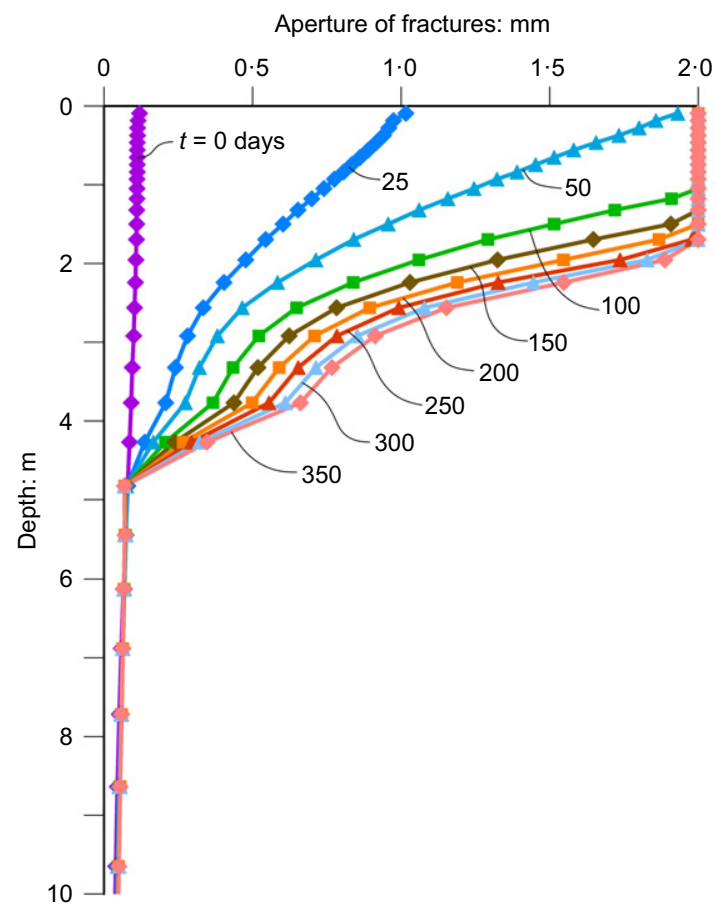

(b)

Fig. 14. Variation with depth of (a) calculated permeability (logarithmic scale) below the flat slab at the axis of the tunnel and (b) calculated aperture of fractures below the flat slab at the axis of the tunnel; $t=0$ days corresponds to the beginning of the crystallisation process 


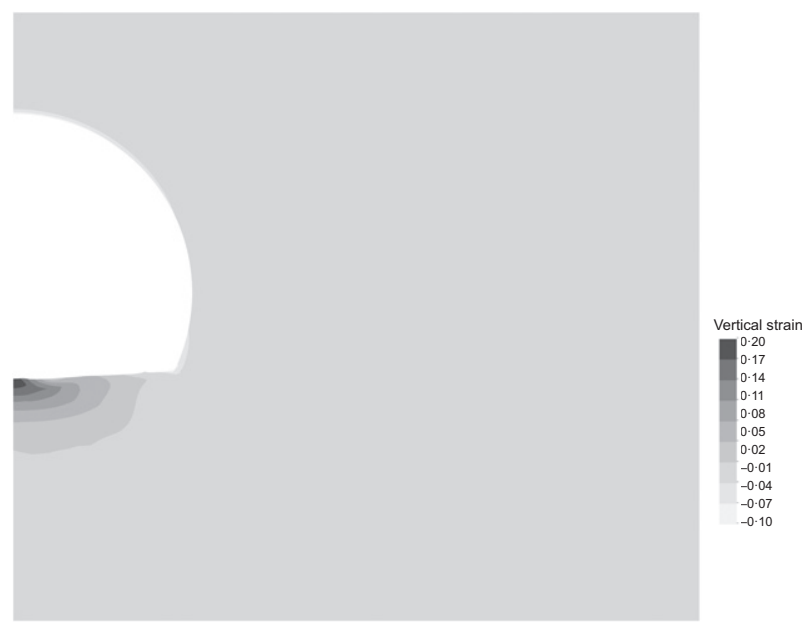

Fig. 15. Distribution of the magnitude of vertical strains after 365 days of gypsum crystallisation. Positive strain values: swelling

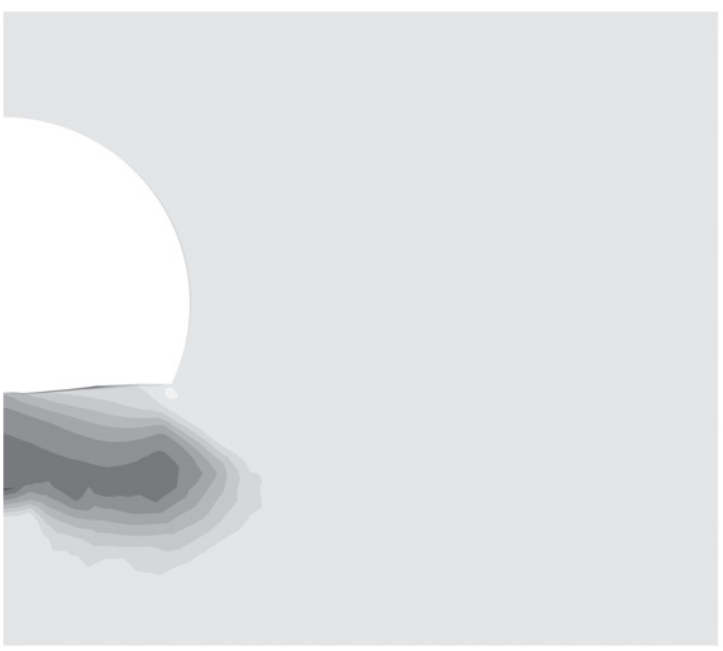

(a)

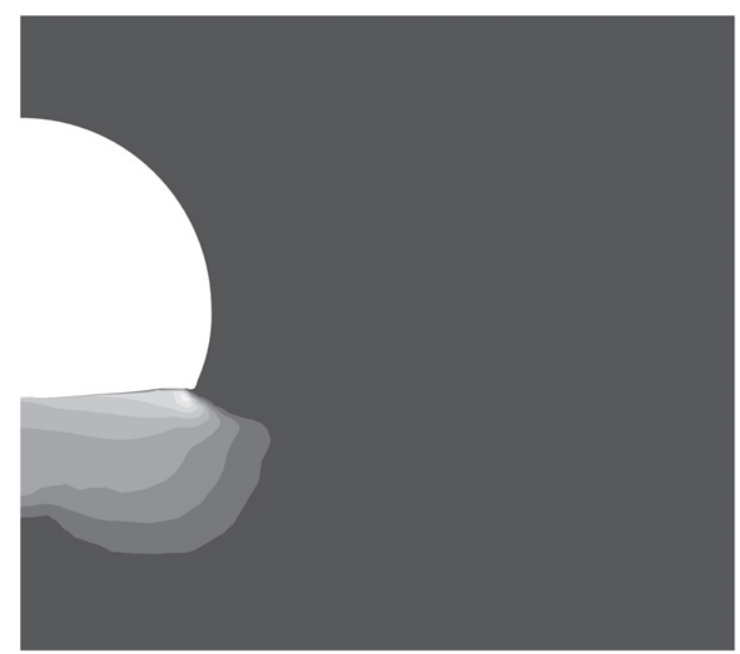

(b)

Fig. 16. Distribution of the volumetric fraction of (a) gypsum and (b) anhydrite after 365 days of gypsum crystallisation

Swelling is attributed to gypsum precipitation from supersaturated sulfate solutions. Sulfate supersaturation requires the presence of water and anhydrite.

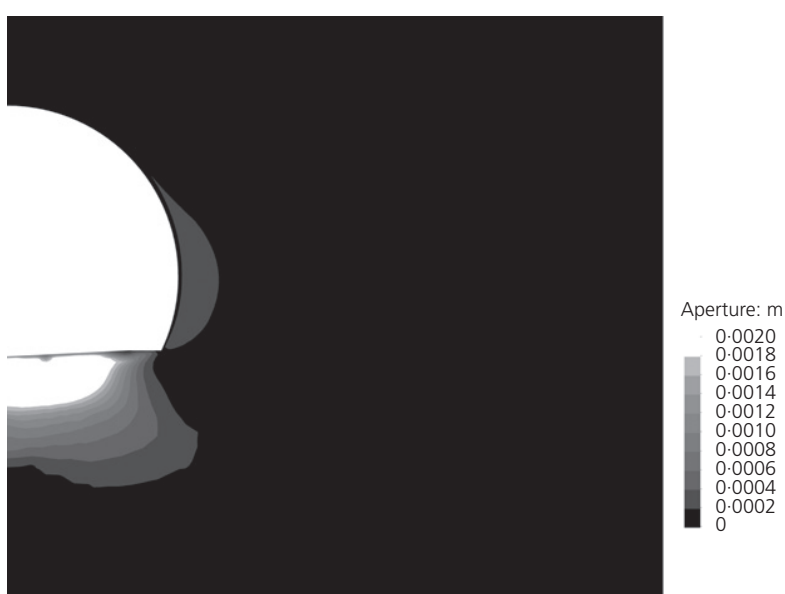

(a)

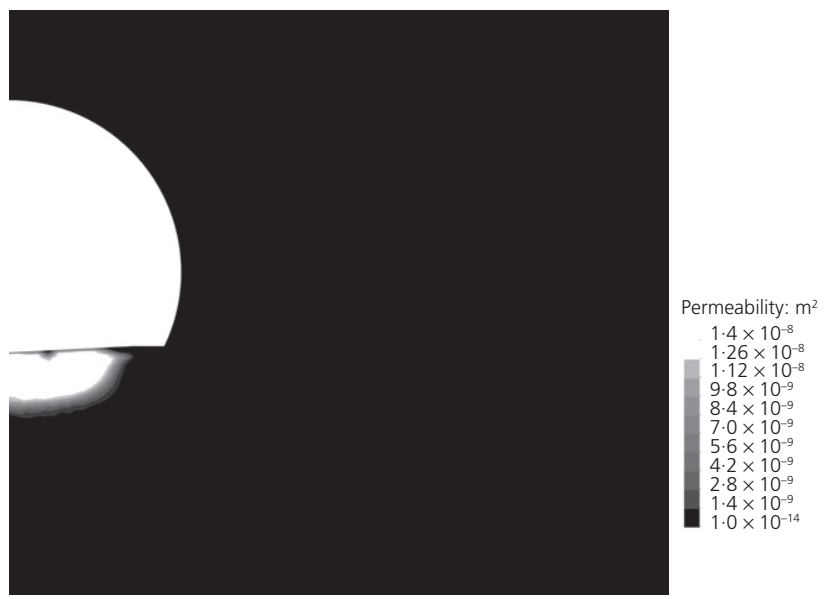

(b)

Fig. 17. Distribution of (a) aperture of fractures and (b) permeability after 365 days of gypsum crystallisation

Supersaturation by evaporation at the tunnel surface was discarded as a relevant mechanism. Kinetic equations were used to describe the precipitation and dissolution rates of gypsum and anhydrite. Previous experience in modelling a singular heaving case provided background information on the kinetic parameters. From a mechanical perspective, a key aspect of the problem is the transformation of precipitated gypsum crystals into rock deformations. This aspect requires further attention because of its relevance. The interpretation of published tests, related to real conditions to some extent, provided some information on 'bulking' and stress effects on the relationship between induced strain and precipitated mass.

Tunnelling excavation and subsequent swelling in brittle sulfated claystones result in an accumulation of damage. In the model, this is attributed to the generation of fissures that exacerbate previous rock fracturing. This mechanism is represented in the finite-element model by means of an embedded fracture, which relies on the interpretation of calculated tensile strains. Crack opening has two distinct effects - it increases fast rock permeability around the tunnel and facilitates the crystallisation of sulfates.

The outlined phenomena and mechanisms form the basis of a version of the finite-element code Code_Bright that is capable of modelling tunnel construction in anhydritic formations.

The model was applied to simulate the behaviour of the well-documented case history of Lilla tunnel, excavated in 


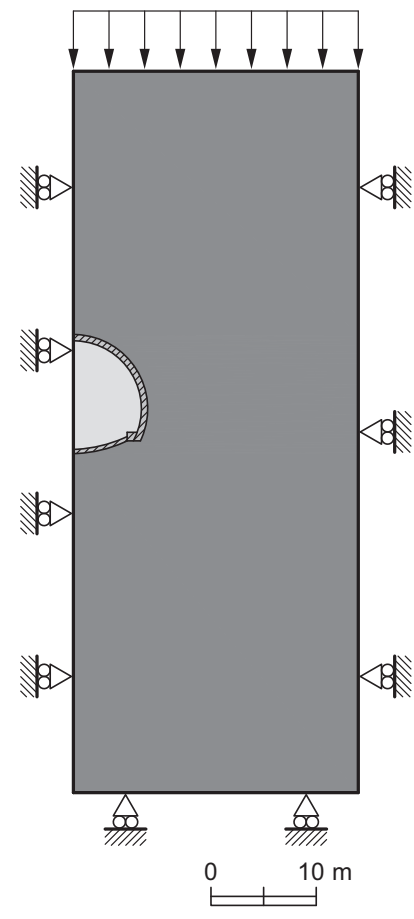

(a)

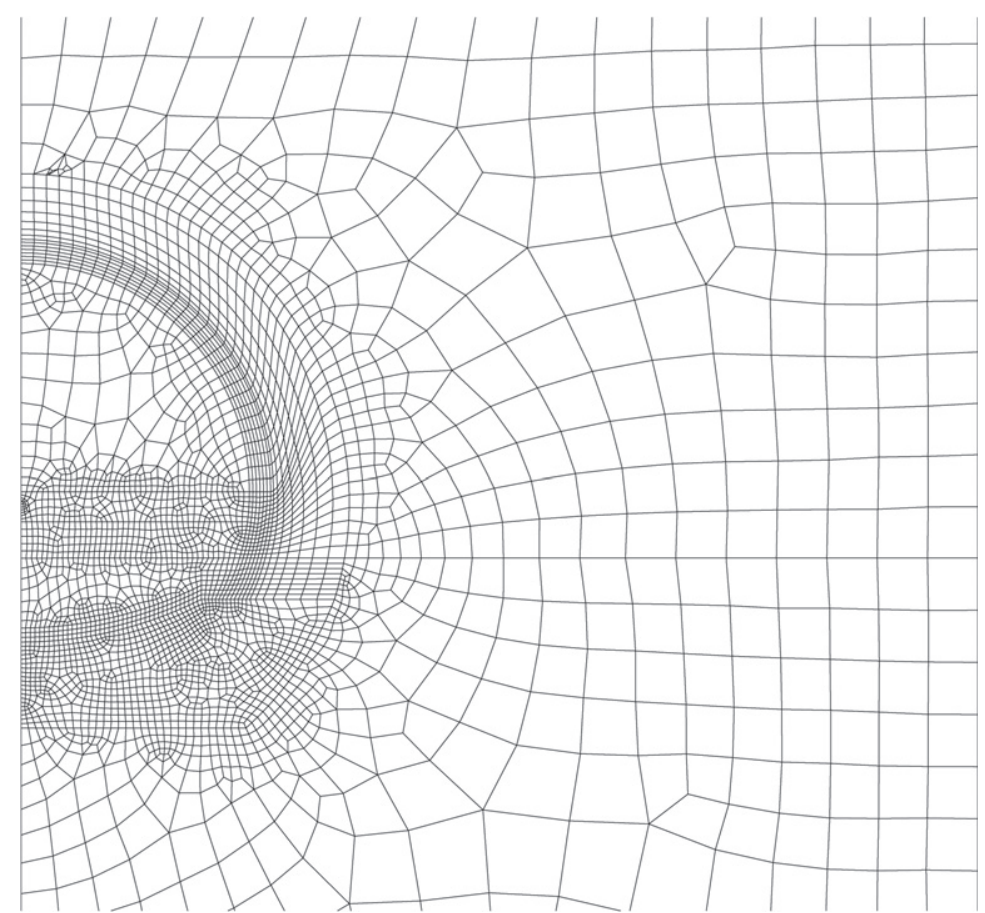

(b)

Fig. 18. Geometry and mesh of the analysis domain used for the simulation of Lilla tunnel with invert arch simulations

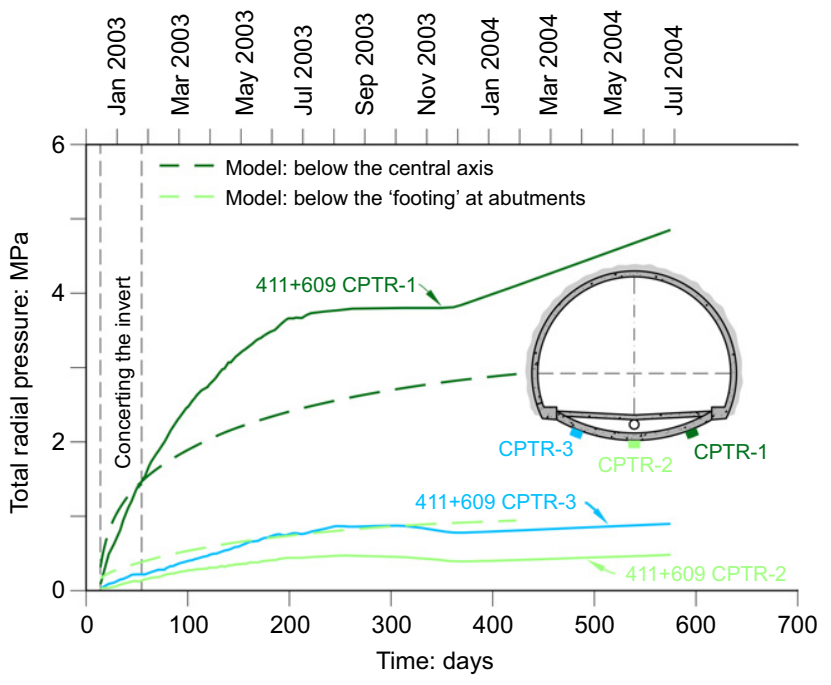

Fig. 19. Development of swelling pressure recorded by stress cells under the invert and evolution of calculated vertical stress after excavation under the concrete invert at the centre and near the abutments

Tertiary sulfated claystones. Field data, namely swelling records observed for more than 1 year in the tunnel floor and the depth distribution of gypsum and anhydrite volume fractions, were compared with model calculations. The numerical analysis also provided information on the evolution and spatial distribution of induced cracking and rock permeability.

The analysis was extended to simulate the construction of a structural invert arch. Field data on the measured swelling pressures against the inverted vault and its vertical displacements were also available. The comparison with model predictions, maintaining the set of parameters describing

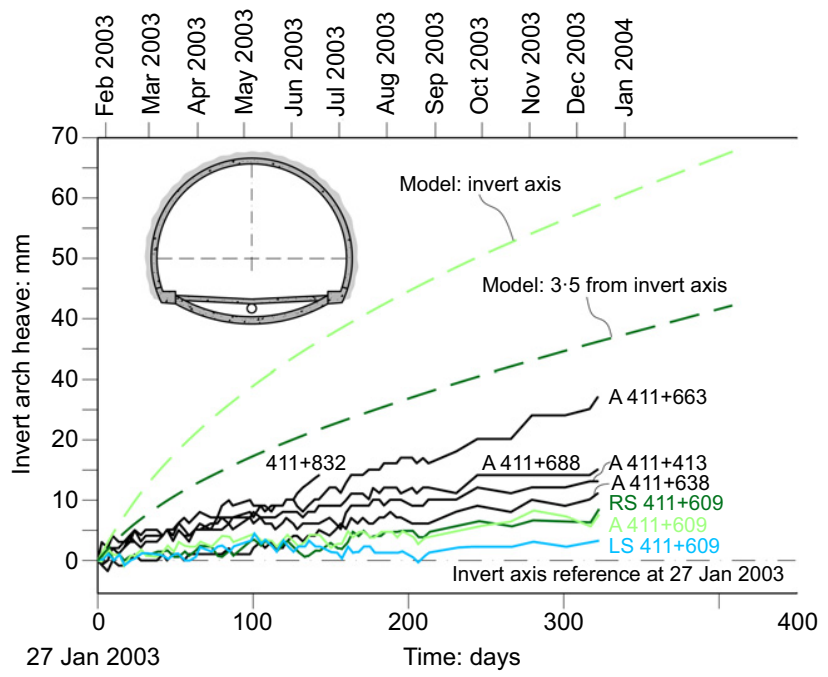

Fig. 20. Calculated vertical displacements of invert arch at chainage $411+600$ and evolution of field measurements of invert heave between January and December 2003

the 'free' floor swelling of the first stage of construction, was fair in general terms.

The preceding positive comments have to be weighted with a few considerations that may help to direct future research on aspects insufficiently known. The observed variability in the field measurements (both displacements and pressures against the tunnel lining (Alonso et al., 2013)) suggests that the mechanisms of crystal growth and propagation in real environments require more precise and comprehensive field data. Details of the described formulation, such as the identification of rate parameters, the significance and appropriateness of threshold fracture opening for crystal precipitation, the simple concept behind fracture opening 
and the role of rock matrix damage, not included in the model, require improvement and further study.

\section{APPENDIX. FORMULATION OF THE MODEL}

The mass balance equation of solid phase in terms of the rate of change of rock porosity, $\phi$, is

$$
\begin{aligned}
\frac{D_{\mathrm{s}} \phi}{D t}= & \left(\frac{\left(1-\phi-\phi_{\mathrm{anh}}-\phi_{\mathrm{gyp}}\right)}{\rho_{\mathrm{s}}} \frac{D_{\mathrm{s}} \rho_{\mathrm{s}}}{D t}+\frac{\phi_{\mathrm{anh}}}{\rho_{\mathrm{anh}}} \frac{D_{\mathrm{s}} \rho_{\mathrm{anh}}}{D t}+\frac{\phi_{\mathrm{gyp}}}{\rho_{\mathrm{gyp}}} \frac{D_{\mathrm{s}} \rho_{\mathrm{gyp}}}{D t}\right) \\
& +(1-\phi) \nabla \cdot \frac{\mathrm{d} \boldsymbol{u}}{\mathrm{d} t}-\frac{1}{\rho_{\mathrm{gyp}}} \frac{\mathrm{d} m_{\mathrm{gyp}}}{\mathrm{d} t}-\frac{1}{\rho_{\mathrm{anh}}} \frac{\mathrm{d} m_{\mathrm{anh}}}{\mathrm{d} t}
\end{aligned}
$$

where $\phi_{\text {anh }}$ and $\phi_{\mathrm{gyp}}$ are the volume fractions of the soluble species anhydrite and gypsum, $\rho_{\mathrm{s}}, \rho_{\mathrm{gyp}}$ and $\rho_{\text {anh }}$ are the densities of the insoluble minerals, gypsum and anhydrite, and $\boldsymbol{u}$ is the displacement vector field for the porous medium.

The mass balance equation for water is described, considering any external sink or source of water, $f^{\mathrm{w}}$, the total mass flux of water in the porous rock as a combination of the velocity of the solid skeleton $\left(\rho_{1}(\mathrm{~d} \boldsymbol{u} / \mathrm{d} t)\right)$ and the Darcy component $\left(\rho_{1} \boldsymbol{q}_{1}\right)$, where $\rho_{1}$ is the density of the water and $\boldsymbol{q}_{\mathbf{l}}$ is the flow rate of water, by

$$
\phi \frac{D_{\mathrm{s}} \rho_{1}}{D t}+\rho_{1} \frac{D_{\mathrm{s}} \phi}{D t}+\rho_{1} \phi \nabla \cdot\left(\frac{\mathrm{d} \boldsymbol{u}}{\mathrm{d} t}\right)+\nabla \cdot\left(\rho_{1} \boldsymbol{q}_{1}\right)=f^{\mathrm{w}}
$$

The external supply or sink of water, $f^{\mathrm{w}}$, takes into account that a quantity of water is incorporated (or released) in the crystalline structure of gypsum when gypsum precipitation or dissolution occurs.

The mass balance equation of solute calcium sulfate reads

$$
\begin{aligned}
\rho_{1} \omega_{1}^{\mathrm{m}} \nabla \cdot\left(\frac{\mathrm{d} \boldsymbol{u}}{\mathrm{d} t}\right) & +\phi \frac{D_{\mathrm{s}}\left(\rho_{1} \omega_{1}^{\mathrm{m}}\right)}{D t}+\nabla \cdot\left(\rho_{1} \omega_{1}^{\mathrm{m}} \boldsymbol{q}_{1}-\mathbf{D} \nabla \omega_{1}^{\mathrm{m}}\right) \\
& =-\frac{\mathrm{d} m_{\mathrm{gyp}}}{\mathrm{d} t}\left(1-\frac{\rho_{1} \omega_{1}^{\mathrm{m}}}{\rho_{\mathrm{gyp}}}\right)-\frac{\mathrm{d} m_{\mathrm{anh}}}{\mathrm{d} t}\left(1-\frac{\rho_{1} \omega_{1}^{\mathrm{m}}}{\rho_{\mathrm{anh}}}\right)
\end{aligned}
$$

The product $\rho_{1} \omega_{1}^{\mathrm{m}}$ is the concentration of calcium sulfate in water in units of mass/volume, where $\omega_{1}^{\mathrm{m}}$ is the mass fraction of dissolved calcium sulfate in water. The term $\mathbf{D} \nabla \omega_{1}^{\mathrm{m}}$ describes the diffusive rate of flow following Fick's law, where $\mathbf{D}$ is the diffusion coefficient.

The kinetic equation for the dissolution/precipitation of gypsum is given in equation (2). A similar equation was adopted for anhydrite.

The equilibrium mass fractions of calcium sulfate in saturated conditions in equation (2) are derived from consideration of the pressure applied to the crystal, $p$, and the temperature, $T$. Scherer (1999) describes the effect of stress acting on the crystals (gypsum and anhydrite) as

$$
\omega_{1_{\mathrm{sat}}}^{\mathrm{m}}=\omega_{01_{\mathrm{sat}}}^{\mathrm{m}} \exp \left(\frac{p v_{\mathrm{c}}}{R_{\mathrm{g}} T}\right)
$$

where, $\omega_{01_{\text {sat }}}^{\mathrm{m}}$ corresponds to the equilibrium mass fraction of dissolved calcium sulfate in water for an unloaded crystal, $v_{\mathrm{c}}$ is the molar volume of the crystal, $R_{\mathrm{g}}$ is the ideal gas constant and $T$ is the absolute temperature.

The loading pressure applied on the crystals is made equal to the vertical effective intergranular stress acting on the solid species $\sigma_{\text {crystal }}^{\prime}$ (Ramon \& Alonso, 2013)

$$
p=\sigma_{\text {crystal }}^{\prime}=\frac{\sigma_{z}^{\prime}}{1-\phi}
$$

where $\sigma_{z}^{\prime}$ is the vertical effective stress. The equilibrium equation in terms of total stresses

$$
\nabla \cdot \boldsymbol{\sigma}+\boldsymbol{b}=0
$$

\begin{tabular}{|c|c|}
\hline$a_{0}$ & initial aperture of fractures $(\mathrm{mm})$ \\
\hline$a_{\text {crit }}$ & minimum fracture aperture for precipitation $(\mu \mathrm{m})$ \\
\hline$a_{\max }$ & maximum aperture of fractures $(\mathrm{mm})$ \\
\hline$b$ & parameter defining $\gamma_{i}(1 / \mathrm{MPa})$ \\
\hline $\boldsymbol{b}$ & vector of body forces (MPa) \\
\hline$c$ & current sulfate concentration of water \\
\hline D & diffusion coefficient $\left(\mathrm{m}^{2} / \mathrm{s}\right)$ \\
\hline$D_{\mathrm{s}}$ & material derivative \\
\hline$E$ & elastic modulus \\
\hline$f^{\mathrm{w}}$ & sink or source of water $\left(\mathrm{kg} / \mathrm{m}^{3} . \mathrm{s}\right)$ \\
\hline$G_{\mathrm{s}}$ & specific gravity \\
\hline$K$ & intrinsic permeability $\left(\mathrm{m}^{2}\right)$ \\
\hline$K_{0}$ & rest pressure coefficient \\
\hline$m_{\text {gyp }}$ & precipitated mass of gypsum (kg) \\
\hline$m_{\mathrm{anh}}$ & precipitated mass of anhydrite $(\mathrm{kg})$ \\
\hline$p$ & pressure applied on the crystals (MPa) \\
\hline$q_{1}$ & flow rate of water, advective flow $(\mathrm{m} / \mathrm{s})$ \\
\hline$R_{\mathrm{g}}$ & ideal gas constant (atm.1/(K.mol)) \\
\hline$s$ & spacing between fractures (mm) \\
\hline$T$ & absolute temperature $(\mathrm{K})$ \\
\hline$t$ & time \\
\hline & solid displacement $(\mathrm{m})$ \\
\hline$V_{\mathrm{w}}^{\text {evap }}$ & volume of evaporated water at interface \\
\hline$w$ & water content \\
\hline$\gamma_{i}$ & bulking coefficient in $i$ direction \\
\hline$\gamma_{\max }$ & bulking coefficient for zero pressure stress \\
\hline$\varepsilon_{i}$ & strain in the $i$ direction \\
\hline$\varepsilon_{0}$ & $\begin{array}{l}\text { threshold tensile principal strain to initiate } \\
\text { fracture opening }\end{array}$ \\
\hline$\kappa$ & kinetic constant $\left(\mathrm{kg} / \mathrm{s} \cdot \mathrm{m}^{2}\right.$ of crystal) \\
\hline$\kappa_{\mathrm{anh}}$ & kinetic constant parameter for anhydrite $\left(\mathrm{kg} / \mathrm{s} \cdot \mathrm{m}^{2}\right)$ \\
\hline$\kappa_{\mathrm{gyp}}$ & kinetic constant parameter for gypsum $\left(\mathrm{kg} / \mathrm{s.m}^{2}\right)$ \\
\hline$v$ & Poisson's ratio \\
\hline$v_{\mathrm{c}}$ & molar volume of crystal $\left(\mathrm{m}^{3} / \mathrm{mol}\right)$ \\
\hline$\rho_{1}$ & density of water $\left(\mathrm{kg} / \mathrm{m}^{3}\right)$ \\
\hline$\rho_{\text {anh }}$ & anhydrite density $\left(\mathrm{kg} / \mathrm{m}^{3}\right)$ \\
\hline$\rho_{\text {gyp }}$ & gypsum density $\left(\mathrm{kg} / \mathrm{m}^{3}\right)$ \\
\hline$\rho_{\mathrm{s}}$ & density of solid species $\left(\mathrm{kg} / \mathrm{m}^{3}\right)$ \\
\hline$\rho_{\mathrm{t}}$ & total density \\
\hline$\sigma$ & stress tensor $(\mathrm{MPa})$ \\
\hline$\sigma_{\mathrm{c}}$ & $\begin{array}{l}\text { specific surface }\left(\mathrm{m}^{2} \text { of crystal surface } / \mathrm{m}^{3} \text { of }\right. \\
\text { medium) }\end{array}$ \\
\hline$\sigma_{\text {crystal }}^{\prime}$ & pressure applied on crystals (MPa) \\
\hline $\begin{array}{r}\sigma_{i}^{\prime} \\
\sigma_{z}^{\prime} \\
\phi\end{array}$ & $\begin{array}{l}\text { effective confining stress in the } i \text { direction } \\
\text { vertical effective stress } \\
\text { porosity }\left(\mathrm{m}^{3} / \mathrm{m}^{3}\right)\end{array}$ \\
\hline $\begin{array}{r}\phi \\
\phi_{\mathrm{anh}}\end{array}$ & $\begin{array}{l}\text { porosity }\left(\mathrm{m}^{3} / \mathrm{m}^{3}\right) \\
\text { volumetric fraction of anhydrite }\left(\mathrm{m}^{3} / \mathrm{m}^{3}\right)\end{array}$ \\
\hline $\begin{array}{l}\phi_{\text {gyp }} \\
\phi_{\text {na }}\end{array}$ & $\begin{array}{l}\text { volumetric fraction of anhydrite }\left(\mathrm{m}^{3} / \mathrm{m}^{3}\right) \\
\text { volumetric fraction of gypsum }\left(\mathrm{m}^{3} / \mathrm{m}^{3}\right)\end{array}$ \\
\hline$\tilde{\phi}_{\mathrm{ini}}$ & initial open porosity \\
\hline$\phi_{\text {ini }}^{\text {anh }}$ & initial volumetric fraction of anhydrite $\left(\mathrm{m}^{3} / \mathrm{m}^{3}\right)$ \\
\hline$\phi_{\min }^{\mathrm{gyp}}$ & initial volumetric fraction of gypsum $\left(\mathrm{m}^{3} / \mathrm{m}^{3}\right)$ \\
\hline$\omega_{1}^{\mathrm{m}}$ & mass fraction of dissolved sulfate in water $(\mathrm{kg} / \mathrm{kg})$ \\
\hline$\omega_{1_{\text {sat }}}^{\mathrm{m}}$ & $\begin{array}{l}\text { current equilibrium mass fraction of dissolved } \\
\text { sulfate in water }(\mathrm{kg} / \mathrm{kg})\end{array}$ \\
\hline$\omega_{00_{\text {sat }, \text { anh }}}^{m}$ & $\begin{array}{l}\text { equilibrium mass fraction of dissolved sulfate in } \\
\text { water with respect to anhydrite without pressure } \\
\text { applied on crystals }(\mathrm{kg} / \mathrm{kg})\end{array}$ \\
\hline$\omega_{01_{\text {sat, gyp }}}^{m}$ & $\begin{array}{l}\text { equilibrium mass fraction of dissolved sulfate in } \\
\text { water with respect to gypsum without pressure } \\
\text { applied on crystals }(\mathrm{kg} / \mathrm{kg})\end{array}$ \\
\hline
\end{tabular}

where $\boldsymbol{\sigma}$ is the stress tensor and $\boldsymbol{b}$ is the vector of body forces, completes the set of equations to be solved.

The deformations induced by the precipitation of gypsum are imposed during calculations (equations (3) and (4)).
NOTATION

\section{REFERENCES}

Alonso, E. E. \& Olivella, S. (2008). Modelling tunnel performance in expansive gypsum claystone. In Proceedings of the 12th conference of international association for computer methods and advances in geomechanics (IACMAG) (ed. M. N. Jadhav), pp. 891-910. Red Hook, NY, USA: Curran Associates (CD-ROM).

Alonso, E. E. \& Ramon, A. (2013). Heave of a railway bridge induced by gypsum crystal growth: field observations. Géotechnique 63, No. 9, 707-719, http://dx.doi.org/10.1680/ geot.12.P.034. 
Alonso, E. E., Berdugo, I. R., Tarragó, D. \& Ramon, A. (2007). Tunnelling in sulphate claystones. Invited Lecture. In Proceedings of the 14th European conference on soil mechanics and geotechnical engineering - geotechnical engineering in urban environments (eds V. Cuéllar, E. Dapena, E. Alonso, J. M. Echave, A. Gens, J. L. De Justo, C. Oteo, J. M. Rodríguez-Ortiz, C. Sagaseta, P. Sola and A. Soriano), vol. 1, pp. 103-122. Rotterdam, the Netherlands: Millpress.

Alonso, E. E., Berdugo, I. R. \& Ramon, A. (2013). Extreme expansive phenomena in anhydritic-gypsiferous claystone: the case of Lilla tunnel. Géotechnique 63, No. 7, 584-612, http://dx. doi.org/10.1680/geot.12.P.143.

Amstad, C. \& Kovári, K. (2001). Untertagbau in quellfähigem Fels. Zurich, Switzerland: Eidgenössisches Departement für Umwelt, Verkehr, Energie und Kommunikation (UVEK) and Bundesamt für Strassen (ASTRA) (in German).

Anagnostou, G. (1992). Untersuchungen zur Statik des Tunnelbaus in quellfähigem Gebirge. $\mathrm{PhD}$ thesis, ETH Zurich, Zurich, Switzerland (in German).

Anagnostou, G. (1993). A model for swelling rock in tunnelling. Rock Mech. Rock Engng 26, No. 4, 307-331.

Anagnostou, G. (1995). Seepage flow around tunnels in swelling rock. Int. J. Numer. Analyt. Methods Geomech. 19, No. 10, 705-724.

Anagnostou, G. (2007). Design uncertainties in tunnelling through anhydritic swelling rocks. Felsbau - Rock and Soil Engineering 25, No. 4, 48-54.

Anagnostou, G., Serafeimidis, K. \& Vrakas, A. (2015). On the occurrence of anhydrite in the sulphatic claystones of the gypsum Keuper. Rock Mech. Rock Engng 48, No. 1, 1-13.

Barla, M. (2008). Numerical simulation of the swelling behaviour around tunnels based on special triaxial tests. Tunn. Undergr. Space Technol. 23, No. 5, 508-521.

Butscher, C., Huggenberger, P., Zechner, E. \& Einstein, H. H. (2011). Relation between hydrogeological setting and swelling potential of clay-sulfate rocks in tunneling. Engng Geol. 122, No. 3-4, 204-214.

Charola, A. E., Pühringer, J. \& Steiger, M. (2007). Gypsum: a review of its role in the deterioration of building materials. Environ. Geol. 52, No. 2, 339-352.

DGEGS (Department of Geotechnical Engineering and GeoSciences of the Polytechnic University of Catalonia) (2017). Code_Bright. Barcelona, Spain: Department of Geotechnical Engineering and Geo-Sciences of the Polytechnic University of Catalonia. See https://www.etcg.upc.edu/recerca/webs/code_ bright (accessed 24/07/2017).

Einstein, H. H. (1979). Tunneling in swelling rock. Undergr. Space 4, No. 1, 51-61.

Einstein, H. H. (1996). Tunneling in difficult ground: swelling behaviour and identification of swelling rocks. Rock Mech. Rock Engng 29, No. 3, 113-124.

Einstein, H. H., Bischoff, N. \& Hoffmann, E. (1972). Verhalten von Stollensohlen in quellendem Mergel (Behaviour of invert slabs in swelling shale). In Proceedings of international symposium on underground openings (eds $\mathrm{H}$. Grob and K. Kovári), pp. 296-319. Zurich, Switzerland: Swiss Society for Soil Mechanics and Foundation Engineering.

Fröhlich, B. (1986). Anisotropes Quellverhalten diagenestisch verfestigter Tonsteine. Karlsruhe, Germany: Veröffentlichung des Inst. f. Boden- und Felmechnik der Univ. Friedericiana (in German).

Goldscheider, N. \& Bechtel, T. D. (2009). Editors' message: the housing crisis from underground - damage to a historic town by geothermal drillings through anhydrite, Staufen, Germany. Hydrogeol. J. 17, No. 3, 491-493.

Grob, H. (1972). Schwelldruck im Belchentunnel. In Proceedings of international symposium on underground openings (eds $\mathrm{H}$. Grob and K. Kovári), pp. 99-119. Zurich, Switzerland: Swiss Society for Soil Mechanics and Foundation Engineering (in German).

Grob, H. (1976). Swelling and heave in Swiss tunnels. Bull. Int. Assoc. Engng Geol. 13, No. 1, 55-60.

Gysel, M. (1977). A contribution to the design of a tunnel lining in swelling rock. Rock Mech. 10, No. 1-2, 55-71.

Gysel, M. (1987). Design of tunnels in swelling rock. Rock Mech. Rock Engng 20, No. 4, 219-242.

Heidkamp, H. \& Katz, C. (2002). Soils with swelling potential: proposal of a final state formulation within an implicit integration scheme and illustrative FE-calculations. Proceedings of the 5th world congress on computational mechanics, Vienna, Austria.

Heidkamp, H. \& Katz, C. (2004). The swelling phenomenon of soils: proposal of an efficient continuum modelling approach. In Rock engineering - theory and practice: proceedings of EUROCK 2004 \& 53rd geomechanics colloquium (ed. W. Schubert). Essen, Germany: VGE.

Henke, K. F. (1976). Magnitude and rate of heave in tunnels in calcium sulphate bearing rocks. Bull. Int. Assoc. Engng Geol. 13, No. 1, 61-64.

Huber, T., Pimentel, E. \& Anagnostou, G. (2015). Experimental investigations for the modelling of chemo-mechanical processes in anhydritic rock. Energy Procedia 76, 87-95.

Huder, J. \& Amberg, G. (1970). Quellung in Mergel, Opalinuston und Anhydrit. Schweiz. Bauz. 88, No. 43, 975-980 (in German).

ISRM (International Society for Rock Mechanics) (1989). Suggested methods for laboratory testing of argillaceous swelling rocks. Int. J. Rock Mech. Min. Sci. Geomech. Abstr. 26, No. 5, 415-426.

Kovári, K. \& Descoeudres, F. (2001). Tunnelling Switzerland. Zurich, Switzerland: Swiss Tunnelling Society.

Kovári, K., Amstad, C. \& Anagnostou, G. (1988). Design/ construction methods: tunnelling in swelling rocks. In Key questions in rock mechanics: proceedings of the 29th US symposium (eds P. A. Cundall, R. L. Sterling and A. M. Starfield), pp. 17-32. Rotterdam, the Netherlands: Balkema.

Kramer, G. J. E. \& Moore, I. D. (2005). Finite element modelling of tunnels in swelling rock. Proceedings of the K.Y. Lo symposium, London, ON, Canada. See http://citeseerx.ist.psu.edu/ viewdoc/summary?doi=10.1.1.543.4557 (accessed 24/07/2017).

Madsen, F. T. (1999). Suggested methods for laboratory testing of swelling rocks. Int. J. Rock Mech. Min. Sci. Geomech. 26, No. 3, 211-225.

Madsen, F., Flückiger, A., Hauber, L., Jordan, P. \& Vögtli, B. (1995). New investigations on swelling rocks in the Belchen tunnel, Switzerland. In Proceedings of the 8th ISRM congress (ed. T. Fuji), vol. 1, pp. 263-267. Rotterdam, the Netherlands: Balkema.

Oldecop, L. \& Alonso, E. E. (2012). Modelling the degradation and swelling of clayey rocks bearing calcium-sulphate. Int. J. Rock Mech. Min. Sci. 54, 90-102, https://doi.org/10.1016/j.ijrmms. 2012.05.027.

Olivella, S. \& Alonso, E. E. (2008). Gas flow through clay barriers. Géotechnique 58, No. 3, 157-176, http://dx.doi.org/10.1680/ geot.2008.58.3.157.

Olivella, S., Carrera, J., Gens, A. \& Alonso, E. E. (1994). Non-isothermal multiphase flow of brine and gas through saline media. Transp. Porous Med. 15, No. 3, 271-293.

Olivella, S., Gens, A., Carrera, J. \& Alonso, E. E. (1996). Numerical formulation for a simulator (Code_Bright) for the coupled analysis of saline media. Engng Comput. 13, No. 7, 87-112.

Parkhurst, D. L. (1995). User's guide to PHREEQC - A computer program for speciation, reaction-path, advective-transport, and inverse geochemical calculations. Water-Resources Investigations Report 95-4227. Denver, CO, USA: US Geological Survey Earth Science Information Center.

Parkhurst, D. L. \& Appelo, C. A. J. (1999). User's guide to PHREEQC (version 2): A computer program for speciation, batch-reaction, one-dimensional transport, and inverse geochemical calculations. Water-Resources Investigations Report 99-4259. Denver, CO, USA: US Geological Survey Earth Science Information Center.

Pineda, J. A., Alonso, E. E. \& Romero, E. (2014). Environmental degradation of claystones. Géotechnique 64, No. 1, 64-82, http://dx.doi.org/10.1680/geot.13.P.056.

Ramon, A. \& Alonso, E. E. (2013). Heave of a railway bridge: modelling gypsum crystal growth. Géotechnique 63, No. 9, 720-732, http://dx.doi.org/10.1680/geot.12.P.035.

Ramon, A., Olivella, S. \& Alonso, E. E. (2009). Swelling of a gypsiferous claystone and its modelling. In Proceedings of the 17th international conference on soil mechanics and geotechnical engineering - the academia and practice of geotechnical engineering (eds M. Hamza, M. Shahien and 
Y. El-Mossallamy), vol. 1, pp. 730-733. Amsterdam, the Netherlands: IOS Press.

Ruch, C. \& Wirsing, G. (2013). Erkundung und Sanierungsstrategien im Erdwärmesonden-Schadensfall Staufen i. Br. Geotechnik 36, No. 3, 147-159 (in German).

Sass, I. \& Burbaum, U. (2010). Damage to the historic town of Staufen (Germany) caused by geothermal drillings through anhydrite-bearing formations. Acta Carsol. 39, No. 2, 233-245.

Schädlich, B., Marcher, T. \& Schweiger, H. F. (2013). Application of a constitutive model for swelling rock to tunnelling. Geotech. Engng 44, No. 3, 47-54.

Scherer, G. W. (1999). Crystallization in pores. Cem. Conc. Res. 29 , No. 8, 1347-1358.

Serafeimidis, K. \& Anagnostou, G. (2013). On the timedevelopment of sulphate hydration in anhydritic swelling rocks. Rock Mech. Rock Engng 46, No. 3, 619-634.

Serafeimidis, K. \& Anagnostou, G. (2015). The solubilities and thermodynamic equilibrium of anhydrite and gypsum. Rock Mech. Rock Engng 48, No. 1, 15-31.

Steiner, W. (1993). Swelling rock in tunnels: rock characterization, effect of horizontal stresses and construction procedures. Int. J. Rock Mech. Min. Sci. Geomech. Abstr. 30, No. 4, 361-380.

Wahlen, R. \& Wittke, W. (2009). Kalibrierung der felsmechanischen Kennwerte für Tunnelbauten in quellfähigem Gebirge. Geotechnik 32, No. 4, 226-233 (in German).

Wittke, M. (2003). Begrenzung der Quelldrücke durch Selbstabdichtung beim Tunnelbau im anhydritführenden
Gebirge, Geotechnik in Forschung und Praxis WBI-Print, vol. 13. Essen, Germany: Glückauf (in German).

Wittke, M. (2006). Design, construction, supervision and long-term behaviour of tunnels in swelling rocks. In EUROCK 2006: multiphysics coupling and long term behaviour in rock mechanics (eds A. van Cotthem, R. Charlier, J.-F. Thimus and J.-P. Tshibangu), pp. 211-216. Boca Raton, FL, USA: CRC Press.

Wittke, W. (1990). Rock mechanics: theory and applications with case histories. Berlin, Germany: Springer.

Wittke, W. \& Pierau, B. (1979). Fundamentals for the design and construction of tunnels in swelling rock. Proceedings of the 4th international congress on rock mechanics, Montreux, Switzerland, vol. 2, pp. 719-729.

Wittke, W. \& Rißler, P. (1976). Bemessung der Auskleidung von Hohlräumen in quellendem Gebirge nach der Finite Element Methode. Aachen, Germany: Veröffentlichung des Institut für Grundbau, Bodenmechanik, Felsmechanik und Verkehrswasserbau der RWTH Aachen (in German).

Wittke-Gattermann, P. (1998). Verfahren zur Berechnung von Tunnels in quellfähigem Gebirge und Kalibrierung an einem Versuchsbauwerk, Geotechnik in Forschung und Praxis WBI-Print, vol. 1. Essen, Germany: Glückauf (in German).

Wittke-Gattermann, P. \& Wittke, M. (2004). Computation of strains and pressures for tunnels in swelling rocks. Tunn. Under. Space Technol. 19, No. 4-5, 422-423. 